\title{
Water and Land: Environmental Governance and Chinese Eco-Development
}

\section{Introduction}

As awareness of the prominent role played by cities in promoting sustainable development has grown, sustainability ideas have diffused into city planning principles at all scales and become embedded into a multiplicity of urban initiatives (de Jong et al., 2015, Shao, 2015, Joss et al 2011). Eco-city development has emerged as one of the key urban forms. As one of the active advocates as well as a vigorous promoter of eco-developments, China has initiated and implemented a vast number of eco-projects in a range of geographical locations and with diverse scales. These eco-developments, although mostly still under construction, have manifested distinctive features that separate them from Western practices as they are characterised by a top-down mechanism in which the government plays a pivotal or even a sole role (Yu, 2014), and a weak ecological modernization development mode that overemphasises the capability of economic advance and technology to address environmental challenges (Chang and Sheppard, 2013, Neo and Pow, 2015).

There are three key reasons why it is of pressing importance to provide detailed analysis of ecodevelopments in China. First, the prominence of China in urban ecological experimentation and its stateled, ecological modernization-guided development approach make it worthy of research interest. This is because while some expect that the Chinese authoritarian policy-making style would be more rather than less amenable to efforts to materialize eco-developments (Neo and Pow, 2015), others argue against this (de Jong et al., 2013). Given the potential significance of eco-developments for realising more sustainable urban futures, debates on whether China can promote an alternative development model matter. Second, despite claims to integrate economic with social and environmental objectives, recent research on Chinese eco-practices suggest that mainstream eco-developments are wedded to the values of ecological modernization and promote, first and foremost, economic growth, and largely ignore issues such as environmental well-being and social equity (Chang and Sheppard, 2013, Cugurullo, 2015, de Jong et al., 2013, Hult, 2015, Joss, 2011, Pow and Neo, 2013, Yu, 2014). Again, there is an urgent need to better understand the challenges to incorporating social issues into eco-development strategies. Third, as numerous eco-projects are progressing, and new initiatives keep emerging across the nation, there is a growing need for an up-to-date and on-the-ground assessment of current practices to inform the timely debate and learning on future eco-development improvements.

This paper dissects the practices and implications of current eco-developments in China. We find a political ecology perspective to be a fruitful way to analyse development. Political ecology provides a helpful counterpoint to ecological modernization interpretations of Chinese environmental policy and eco-development (Xie et al, 2019). Ecological modernization has provided persuasive accounts of policy developments (see for example, Zhang et al 2007; Zhou 2015) and is an important narrative in policy documents for Chongming Island (Ma et al 2017; Xie et al, 2019). While we need to be aware of these high-level environmental policy initiatives, we also must understand how policy affects communities, how development reshapes people's perceptions of their environment and resources, and of people's ability to give voice to the nature of development in their communities. A political ecology perspective is of use here for three reasons. Firstly, political ecology proposes a more relational view of resource use and space and ways of working towards more just socio-environmental relations in planning (Chan, 2015, Hult, 2017). 
As a "vociferous critic of all forms of capitalism" (Neo and Pow, 2015: 406), political ecology provides a critical examination of current pro-growth eco-development practices. Secondly, by questioning who loses and who benefits, and the inclusiveness of these so-called eco-developments, a political ecology framework helps to investigate the forms that eco-projects may take and at what social and ecological cost (Hult, 2017). Therefore, political ecology helps to both critically examine the socio-economic and environmental outcomes of current Chinese eco-developments and identify ways of thinking differently around sustainability so that critically informed policy proposals may also be produced. Third as Yeh (2015) has made clear there is a need for political ecology scholarship of China. Yeh (2015: 628) argues for detailed local analyses to uncover the mosaic of human-environment relations in China. We contribute to this task with our work on Chongming Eco-Island which we use as a case study to critically analyse water and land management practices.

Whilst the focus of our paper is eco development in China and specifically Chongming Eco-Island, our findings are of wider significance. This is because a) the eco-modernist narrative that typifies Chinese development is to be found elsewhere (Rapaport 2015) and so lesson-learning from China becomes more relevant; b) the application of a political ecology perspective to eco-development in China remains novel and so provides a valuable evaluation of its utility; and c) Chongming Eco-Island has been deliberately selected for detailed analysis because of its central role in eco-development in China. Indeed, the Island is of global significance and gained global repute because it was the proposed site of the world's first dedicated eco-city (Head and Lawrence 2008). The contributions of the paper are, therefore, first to develop the political ecology approach in relation to its conceptualisation of the multi-scalar environmental state so that it can be applied to eco-development in China, second to provide critical insights into our understanding of society-environment relations in eco-development, third, to enrich the broader understanding of urban sustainability debates in China, and to do this by fourth, presenting an up-to-date interpretation of past and current development of Chongming Eco-Island.

The remainder of the paper is organised into four sections. Section two is our theory section and begins with a discussion of distinctive Chinese eco-development conditions, before examining the links between political ecology and eco-development in China. Here we theorise political ecology as both a contesting perspective in sustainable/ecological development and as a critical analytical method to examine current Chinese eco-practices. Section three explains the materials and methods in the study. It presents a justification for using Chongming Eco-Island as a case study as well as the focus on the water and land as providing insightful ways to evaluate eco-development planning and practices, especially concerning local resource management. In Section four, we document, how over time, there have been transformations in water and land practices and governance and how these shape our understanding of the ongoing construction of Chongming Eco-Island. The findings are examined from a political ecology perspective. Section five provides a set of conclusions that provide an assessment of the features and effects of Chinese state-led and ecological-modernization guided eco-development (as manifested on Chongming EcoIsland), and the implications of political ecology as a theoretical framework and compelling counter narrative in the analysis of eco-developments.

\section{Theoretical perspective: A political ecology of eco-developments}

The general understanding regarding the eco-city is of a modern urban form in which economy, society and ecology can develop jointly (Shao, 2015). Broadly speaking, an eco-city aims at yielding a harmonious relationship between people and nature and a win-win achievement of development and environment, 
while at the same time expressing concerns for social justice and equity. As a concept, an eco-city is thus deemed implicitly as challenging free market capitalism and indiscriminate use of technology (Neo and Pow, 2015). However, research reveals that contemporary manifestations of the eco-city align closely with the theory of ecological modernization (see Hult, 2013, Joss et al., 2013, Neo and Pow, 2015, Pow and Neo, 2013, Rapoport and Hult, 2017) - an approach committed to both capitalism and high-technology solutions. Underlying the principles of ecological modernization is a firm belief that economic and environmental objectives are complementary (Fisher and Freudenburg, 2001, Keil and Desfor, 2003, Krueger and Gibbs, 2007, Mol et al., 2009). Ecological modernization argues that "sustainable futures can be attained under conditions of a continuously growing capitalist economy" (Keil and Desfor, 2003: 30). Such pro-growth ideology is in line with conceptions of urban entrepreneurialism, through which city authorities mobilize resources and marketing strategies to raise city competitiveness, attract flows of people and capital, and promote economic growth (Chien, 2013a, Chien, 2013b, Prytherch, 2002). This is even evident in the Chinese context that features a state-centric institutional and political system that practices unified central leadership and upward accountability with a performance-based cadre evaluation system (mainly measured by economic criteria) (Pow and Neo, 2013). Consequently, as Neo and Pow (2015: 409) have argued the Chinese pursuit of urban sustainability via the eco-city is "simply a legitimization strategy for pro-growth entrepreneurial cities", which seldom relates to socio-ecological concerns (Chien, 2013a). As such, the myriad of Chinese eco-initiatives are known to have deviated from their original spirit and intention and thus faced heavy criticisms (e.g., Joss and Molella, 2013, Neo and Pow, 2015, Yu, 2012, Yu, 2014).

As critiques of eco-developments became more evident, so more radical concepts of the social production of (urban) nature emerged (Keil, 2003, Swyngedouw, 1997); within these alternative concepts sits political ecology, which unequivocally resists both capitalism and associated modernization thinking (Mol and Spaargaren, 2000, Mol, 2003, Muldavin, 2013, Yeh, 2009). (see Brown and Purcell, 2005, Bryant and Bailey, 1997, Bryant, 1998, Keil, 2003, Robbins, 2011). For its advocates, political ecology is a productive approach that usefully picks up issues that an ecological modernization framework fails to adderess in ecodevelopments, such as the distribution of costs and benefits, and the intensification of social injustice (Yeh, 2009). As these social-economic and environmental challenges and problems are also shown in the majority of Chinese current eco-developments (e.g. Caprotti, 2014a, Caprotti, 2014b, Caprotti et al., 2015, Grydehøj and Kelman, 2016, Hodson and Marvin, 2010), there is a need for political ecology thinking and analysis that may foster a more environmentally sound, economically sustainable and socially just ecodevelopment. It involves a shift in approach that draws heavily on textual analyses of state policies and plans alongside key person interviews to investigating the practices of eco-developments. This is important because it enables us to more clearly identify tensions and contradictions between state policy and practice and it also enables us to develop a more nuanced perspective on the Chinese environmental state.

A political ecology approach also incorporates a host of stakeholders and actors (especially those marginalized groups) into the research scope (Bryant and Bailey, 1997, Robbins and Sharp, 2003, Swyngedouw, 2004, Yeh, 2009). Rooted in the political ecology concept is the assertion that environmental issues are not solely a subject of natural science, but are inherently associated with political, economic and social actions, and more precisely, with questions about place and power (Bryant, 1998). Often, the power of different actors is conceptualized by their ability to control access to valued environmental resources and the economic benefits ensuing from resource exploitation (see Bryant and 
Bailey, 1997, Tan-Mullins et al., 2017). As stakeholders are empowered by different resources such as knowledge and technology as well as access to information (Tan-Mullins et al., 2017), they gain uneven power to effect change on the environment. Stakeholders may also have distinct perceptions of natural resources (Bryant and Bailey, 1997, Hung and Sheu, 2010, Neumann, 2005, Peet et al., 2011, Robbins, 2011), and as we shall see in our case study below local actors perceive their environment in a different way to external planners. In the Chinese case where the state has such power it is important to recognize its disproportionate and overwhelming influence in environmental interventions, and that these may often lead to unintended and even pernicious socio-environmental results (Bryant and Bailey, 1997, Neumann, 2005, Peet et al., 2011, Robbins, 2011) (again as we shall see in our case study with the canalisation of a river). As most eco-developments in China are initiated and implemented by governments at multi-levels in cooperation with other state actors (such as state-owned enterprises), non-state actors' voices are often muted (or absent) during the policy-making process. Thereby, political ecology opens up opportunities for our research on opaque actors in eco-developments such as farmers to yield more understanding of the operation of power and discourse in practice, and to further reveal governing logics and state power.

We also need to recognise the distinctive ways in which environmental, political and social debates play out in China and how these may contribute to a vibrant political ecology research agenda. Although there are many points that could be raised to highlight the distinctiveness of political ecology in China we wish to concentrate on four. First, there is a need to recognise state authoritarianism (Xie, 2015), which shapes the development process, opportunities for participation and dominant interpretations of nature and resources. The state is also riven by tensions as it acts as both developer and protector of the environment, and these tensions play out in spatially complex patterns, so suggesting the need for detailed local analysis. Second, there is a narrative that rural villagers are backward and unwilling to manage land in an environmentally sensitive manner, which helps provide a rationale for state activity (Yeh, 2015). As we shall see, on Chongming Island there are competing knowledge claims between local know-how and external professional expertise. Third, recognition needs to be given to the ways in which the environment is constructed, reconstructed and deconstructed (Leff, 2015). Both ecological modernization and Chinese policy have a narrower view of the environment than that to be found in political ecology. A more anthropocentric perspective matters greatly in how win-win outcomes can be created by state actors. The result, though, may be an unduly restrictive perspective on resource efficiency that, for example, concentrates on a single resource such as water and underplays connections between resources. Meanwhile, residents on Chongming tend to have a more intuitive and eco-centric perspective on the environment which rejects or at least does not connect with an anthropocentric rationality. For example, water and land are regarded as intimately related and so trade-offs between the two to promote resource efficiency are discounted. Moreover, where an ecological modernisation perspective may seek resource efficiency gains at multiple scales, for the residents of Chongming Island there is a rootedness to their resource management at the local level. By recognising these tensions, we can examine the potential for local forms of resistance in society-environment relations, though recognising that opportunities are curbed by state authoritarianism. Fourth, the island is also a rural space, the traditional heart of political ecology (Leff, 2015), but which is part of the much larger urban-industrial complex of Shanghai that drives processes of scaling (Barca and Bridge, 2015). In a state-driven economy planning and development become both contextual and explanatory factors in our account of ecological relations on Chongming. For example, Chongming can be portrayed as an eco-island, almost detached from Shanghai, a place that is to be a model of sustainable work and living. Chongming can also be described as the green lungs of 
Shanghai, in which case it becomes possible to justify further urban land intensification because a highquality green space is being preserved within the city boundary. Both constructions of Chongming have implications for the citizens of the Island and whether or not spaces within a city can be socially, environmentally and economically equitable.

Therefore, political ecology, within this research, both serves as a productive and persuasive theoretical framework that gives emphasis to socio-environmental changes and effects, that is inclusive of stakeholders, and has a normative component to help our assessment of current Chinese ecodevelopment practices. Perhaps not surprisingly given the severity of resource and pollution problems in China, political ecology is becoming an increasingly attractive perspective for researchers. For example, there are important recent studies of water scarcity and its management (Clarke-Sather 2017; Wang et al 2018). These studies of access to resources are valuable for the insights that they provide into unfolding state-nature relationships in more marginal areas of China. Our study, into the governance and management of environmental resources on Chongming (with explicit focus on water and land), also provides a useful complement by exploring the relationships between residents, the state and the environment where there is an explicit effort to raise environmental quality via an eco-development. Pow (2018) in his analysis of the Sino-Singapore Tianjin Eco-City is reporting a case with similarities. There are, though, key differences between the Tianjin eco-development and that in Chongming: the former is largely taking place on very poor-quality underdeveloped land, with a very small resident population; whereas the latter is occurring in a place that is recognised for the quality of its rural environment and has well established towns and villages where the effects of development will ripple out into communities. Since an eco-development should at a minimum maintain and more likely seek to enhance the quality of the local environment of Chongming, we, therefore, have a novel context in which to explore the efficacy of a political ecology approach. Key questions that need to be asked in our case study (see below) are: How do state and local understandings of ecological management interact on Chongming Island? How do communities respond to state-led eco-development? How can we progress thinking on political ecology to better analyse multi-scalar state led environmental activities?

\section{Case selection and methodology}

In this research, we ground our analysis via an in-depth case study of the Chongming Eco-Island development in Shanghai, China. Since the late 1990s, Chongming has become central to Chinese ecodevelopment practices and has embodied the features and witnessed the evolution of Chinese sustainability innovations and ideals. In 1996, Chongming Island was selected as one of the pilots for constructing the National Ecological Demonstration Zone, and successfully attained the award in 2002 (MEP, 2002). In 2005, the Dongtan Eco-city project, which is located at the east end of Chongming, was launched with a claim to be the world's first purpose-built eco-city (Arup, 2008, Head and Lawrence, 2008). The project quickly made headlines across the world as it represented China's first attempt at building a sustainable urban model from scratch (Pow and Neo, 2013). However, due to a complicated set of political reasons and ecological concerns (cf. Chang and Sheppard, 2013, Cheng and Hu, 2010), this renowned project has been indefinitely suspended since 2008. Nevertheless, its planning and development ideas and methodology have, in some respects, induced the wider plan of Chongming Eco-Island (Chang and Sheppard, 2013), and further inspired subsequent eco-initiatives in China (such as the flagship SinoSingapore Tianjin Eco-city) (Chang and Sheppard, 2013, Pow and Neo, 2013). Since the plan for building Chongming Eco-Island was announced in 2006, the Island has undergone more than a decade's construction, and now there is an ambition to build a world-class eco-island (Shanghai Municipal 
Government, 2016b). Therefore, understanding Chongming Eco-Island, to some extent, contributes to the achievement of a deep insight into urban sustainable/ecological practices in China. Meanwhile, whilst the majority of eco-city practices in China are conceived of or delivered primarily in terms of technological innovations, Chongming Eco-Island has been recognized as prioritizing a more integrated sustainability vision and planning approach (Joss et al., 2011). It is anticipated by UNEP that Chongming Island can serve as a model of China's eco-progression, and an example of developing an ecological economy for less developed regions of the world (UNEP, 2014: 96). With a relatively good reputation among Chinese ecodevelopment practices, Chongming Eco-Island serves as an ideal case for our critical examination of current Chinese ecological-modernization-led eco-developments. Moreover, the existing complex social structure, the abundant ecological resource, and the rich historic and cultural contents of Chongming Island give it both political and ecological value. Whilst a significant number of eco-cities are being built in the tabula rasa way located on brownfield sites and largely constructed from scratch (Joss et al., 2011), Chongming Eco-Island is planned and built on high quality rural land with diverse landscapes ranging from wetlands, crop fields, and forest. It is home to more than 500,000 people who have a rich history and culture. Chongming thus provides an apt setting for a political ecology analysis of human-nature interactions in Chinese eco-developments.

The empirical section of this paper draws heavily on the interview data, triangulated with archival research and on-site observation. From the data collection, we initially identified two key themes in understanding and evaluating the effects of Chongming Eco-Island development, namely water and land. According to Smil (1993), an enquiry into the biospheric foundation of any modern society must start with a close examination of water and land resources. In Chongming's case these two resources are essential components of the local ecosystem. As an alluvial island formed by deposits of the Yangtze River, Chongming is a large, flat, fertile wetland area with thousands of rivers and ditches, and many lakes and ponds. Examining the changing status of water and land on the Island can thus shed light on the environmental governance on and of Chongming throughout its recent history, especially during the ecodevelopment process. Meanwhile, as a large agricultural rural settlement, water and land are of great significance for the construction of local living and culture. Indigenous people have for a long time relied on the relationship between water and land for growing food and have formed a strong connection with the local environment. Therefore, evaluating the effects of Eco-Island development on local understandings of water and land and their further impacts on the local economy and society is key to understanding human-nature relationships and how those have been shaped and reshaped by the recent eco-developments. In interpreting how water and land are managed, we then developed our third theme, governance. This covered the relationships between key actors (e.g. state institutions, citizens, enterprises) and forms of policy delivery (e.g. regulations, masterplans). Moreover, by placing our research on ecodevelopments on Chongming around water and land it echoes and enriches the continuing debates over "place" and "resource" in political ecology scholarship (see e.g. Bryant and Bailey, 1997; Hung and Sheu, 2010). We continually reflected on and refined our themes of water, land and governance throughout the data collection and analysis phases of the work.

Using the lens of water and land to conduct a political ecology study of Chongming Eco-Island, we firstly explored the abundant written records and archives of the Island. We began with the historical records, including multiple versions of Chongming County Chorography, genealogies, and local gazetteers, to learn about the governance and management of water and land on Chongming in the past. This provides crucial context for our later critical evaluation of contemporary environmental governance during the Chongming 
Eco-Island development. Meanwhile, we also drew on information through a thorough analysis of official policies and plans, development statistics, reports from both governmental and non-governmental organizations, press coverage, and academic publications that are related to the plan and implementation of Chongming Eco-Island. This further helps us to understand the rationale, formulation, and implementation of the Eco-Island development. In addition, we also referred to folk literatures of Chongming that often depict local living, culture and customs, and social life, wherein the local landscape and environment would be described, and thus present us with a more local and social perspective on the developments on Chongming.

Informed by these rich secondary data sources, we then took our research to the field. From November 2016 to September 2018, we have conducted nine fieldwork visits to Chongming with an average duration of six days. During these field surveys, alongside on-site observation, we have conducted key person, semistructured interviews on Chongming Island as well as in the city of Shanghai, involving both experts (such as governmental officials, planners, academic researchers) (see Table 1 below) and non-experts (such as farmers, indigenous residents, and tourists).

Table 1 Key person interviewees and research themes

\begin{tabular}{|c|c|c|}
\hline Interviewee background & Number of interviews & Research themes \\
\hline $\begin{array}{l}\text { Planning and land development } \\
\text { professionals }\end{array}$ & 6 & \multirow{4}{*}{$\begin{array}{l}\text { - Past and current governance of } \\
\text { Chongming } \\
\text { - Approaches to policy delivery } \\
\text { - Resource management (water and } \\
\text { land) } \\
\text { - Perceptions of Eco-Island } \\
\text { development }\end{array}$} \\
\hline Academic experts & 6 & \\
\hline Local cadres & 3 & \\
\hline $\begin{array}{l}\text { Representatives of local } \\
\text { enterprises }\end{array}$ & 2 & \\
\hline
\end{tabular}

Initially our key person interviewees were identified from academic papers, planning documents and media reports. Interviewees were selected for their knowledge of the research themes that we were investigating. This purposeful approach to interviewee identification was complemented as the interviews progressed by 'snowballing techniques' (Taylor, 1993:16) in which our participants were asked to identify and recruit additional key informants. The key person interviews ended when a) our snowballing approach was leading to suggestions of interviewees who we had already contacted and b) interviewees were reinforcing rather than adding to knowledge. Although we endeavoured to cover all our research themes in each interview inevitably our interviewees made variable contributions. For example, our academic experts and planning professionals were more able to discuss resource management topics than other interviewees. Meanwhile, the local cadres and representatives of local firms were able to provide valuable insights into governance on the Island. All interviewees were able to contribute to discussions on the nature of Eco-Island development.

In undertaking the interviews and identifying interviewees we were sensitive to our understanding of the authoritarian state. We carefully listened to the voices of those who spoke to us to detect nuances in meaning. We also actively sought out those who are not typically heard (such as farmers, older people and women). These people were likely to provide a different perspective on local resource management and eco-development (especially about water and land) to our key person interviewees. To identify community members, we sought to gain access to individual informants and groups via gatekeepers and via acquaintances who then acted as our sponsors (Bryman, 2012). This was a strategic approach to allow 
us to gain access to as wide a range of individuals relevant to our research as possible rather than sampling research participants on a random basis. The approach worked as follows. In the early stages of the research, we reviewed on-line sources for public opinions concerning the eco-island development. We identified a local resident who is active in disclosing environmental destruction on the Island and in petitioning local authorities about environmental measures. An interview with this local environmental activist provided us with rich knowledge about what it means to be a local person experiencing adverse environmental impacts from eco-development. Through this local activist we came to meet others. For instance, to gain knowledge of river management projects we asked about who performed such tasks and were introduced to one of the first "river cleaners" on Chongming who shared details of their work. While to better understand more traditional river management practices we gained access to a former village head who explained annual collective river-dredging activities. In total, we conducted 28 semi-structured interviews with residents, indigenous farmers, and tourists. These in-depth semi-structured interviews were conducted individually or jointly, and usually lasted between 60 and 120 minutes.

The levels of trust that we were able to develop in the local community culminated in three informal focus group meetings with villagers from Hongqiao Village in 2018. The first one was on 31 March 2018 and lasted for three hours. The meeting was attended by three male and one female elderly (above 60 years old) villagers. One participant was a former local production team leader who managed collective activities during the 1980s. They shared their memories of the Island's past and their life changes and their attitudes towards the eco-developments on the Island since the 2000s. Following this, another two informal focus group meetings were carried out on September 12, 2018. The first was with three male and two female elderly villagers and the second with four male and three female elderly villagers, involving one "river cleaner", one former village head, and one current local village cadre. These interviews and meetings had three objectives: 1) provide a voice for grassroots' accounts of environmental changes on the Island, and policy and planning implementation and their consequences; 2) address how local stakeholders perceive ecology, environmental protection and improvement, socioeconomic progress, and the notion of an eco-island; and 3) understand and further evaluate the on-theground construction in detail.

The archival material, collection of policy and planning documents, journal articles, interviews, observations, field notes and images formed our database. In interpreting the data and selecting material for detailed analysis we were guided by our three overarching themes: water, land and governance. The themes were broken down into more detailed topics (e.g. historical and contemporary accounts of water management, perceptions of environmental change) and material coded. Throughout, we reflected on the robustness of our themes and the topics and both went through a process of refinement. For instance, as our understanding of the physical nature of the Island and of the Island community developed so we investigated our themes in different ways to better understand the relationships between people and place. This provided an ongoing check on our interpretation, since our informants would challenge our thinking by providing different accounts or additional information. It was important for us to be confident that we understood what people were saying to us and why they were saying it so that we could interpret their meaning. While we wished to report the voices of our key person interviewees and community participants we could only do so if we properly understood what they were saying to us (as well as why they may be quiet). It was only at the point where we felt that there was little additional value in collecting further primary data (see above) that we ended that phase of our work. As this study presents both official narratives and implementation practices, and alternative perspectives provided by some of our key 
person interviewees as well as community voices, we can provide a much richer and nuanced analysis of development on Chongming Eco-Island (see below) than would otherwise have occurred.

\section{Results and discussion: water and land in the development of Chongming Eco-Island}

The empirical material is organised to draw out the key environmental and economic issues shaping the development of Chongming Island. Within these themes particular attention is paid to the ways in which local people and external actors seek to manage and reshape water and land resources. With our political ecology perspective, we provide an historical account of the relationship between people and place and how that has shaped their environment. A longer-term narrative avoids the ahistoricism that can characterise case studies and also makes it analytically more straightforward to evaluate whether ecodevelopment proposals for Chongming mark a break with previous environmental management strategies or are better understood as a continuation of longer-term development initiatives and their relationship to the environment. We argue that place matters to people, that people's experiences of their environment on a day-to-day basis shape how they perceive resource and environmental changes, and that a political ecology approach is giving a voice to those who are marginalised in the policy-making process. Whilst local communities and some key actors are becoming increasingly aware of the tensions in seeking to promote eco-development on Chongming Island, influences from ecological modernisation are likely to remain highly significant in official policy narratives.

An analysis of the Chongming Eco-Island project cannot sidestep its precursor - Dongtan eco-city. Empirical research digging into the genesis and development of the Dongtan eco-city has unveiled its commitment to a weaker form of sustainability, which aims to integrate economy with ecology (but lacks a similar analysis of social development), more bluntly, to capitalize on the available natural resources to promote economic development (Chang and Sheppard, 2013, Sze, 2015). Adopting a key tenet of ecological modernization that the eco-city can be built through a "technological fix", the plan of Dongtan project featured novel environmental technologies and green industries. Although not much of the facilities outlined in the plan has materialized at Dongtan (Den Hartog et al, 2018), the Dongtan wetland park and a wind farm that consists of 13 wind turbines are evidence on the ground of this ambitious plan. Whilst Dongtan eco-city project has stalled since 2008, its planning idea(I)s and methods have been extended to the broader plan of Chongming Eco-Island (Chang and Sheppard, 2013).

\section{Water management in the past: collective efforts}

To fully appreciate the relationship between local people and their environment on Chongming it is necessary to understand the nature of the environment and the shifts in the management of that environment that have taken place. The Island is critically dependent on its management of water. The embryonic sandbanks of Chongming Island are recorded as surfacing from the estuary of the Yangtze River in the late $7^{\text {th }}$ century, and gradually grew, expanded and merged together. Since the reign of Emperor Zhiyuan in the Yuan Dynasty (1264-1294), key rivers in the east and west of the Island stabilized as people constructed many secondary rivers. Over time, these rivers in turn were connected by ditches and drainage channels to draw water into crop fields ${ }^{1}$ (see Figure 1). The ongoing management of the water system has been crucial for the agricultural development of Chongming and provided the base for the

\footnotetext{
${ }^{1}$ For details please refer to Chongming County Chorography Draft (1960) and Chongming County Chorography (1984).
} 
local economy. While water was a valuable environmental resource, it was also a source of vulnerability for the islanders who had to cope with flood risks due to the tidal variations and sedimentation effects which could silt up rivers and ditches. Thus, water courses on Chongming require regular dredging and maintenance. According to Chongming County Water Affairs Bureau (Marine Bureau) (2014), at the end of 2012 , there were a total of 15,923 rivers on the Island, running for $9,352.30$ kilometers.

Figure 1: Chongming Island's water conservancy status in 1984

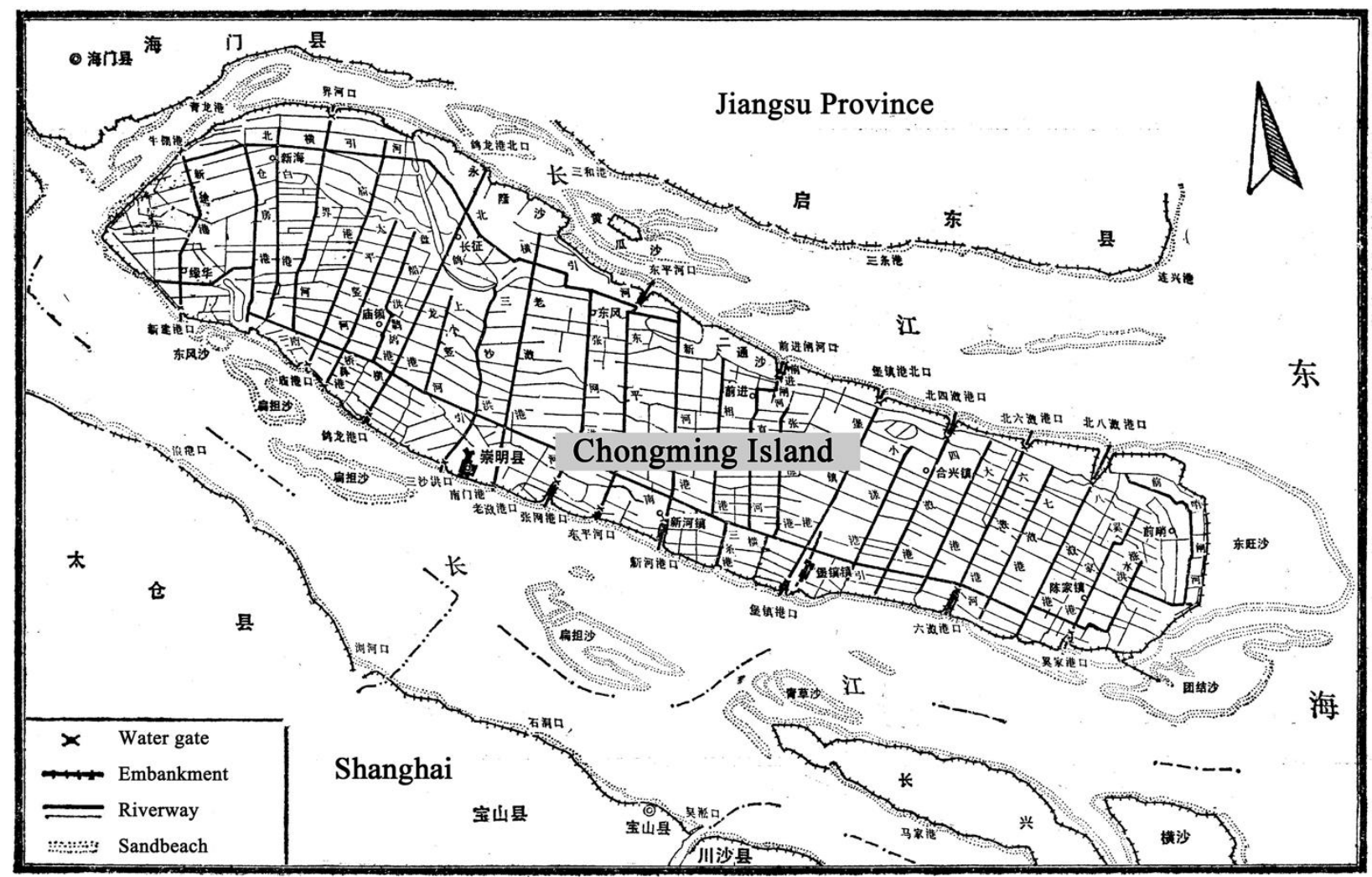

Source: Based on Chongming County Chorography (1984)

As Figure 1 illustrates, generations of Chongming Island dwellers have created a crisscrossing network of waterways that bring water into the hinterland to desalinate soil and irrigate crops in fields (Wei, 1983). The efforts of successive local governors and local landowners to maintain watercourses are well documented in versions of the Chongming County Chorography. However, the Chongming Chorography Draft published in 1960 points out that peasants were the actual major force in water management ${ }^{2}$, and the following Chongming County Chorography published in 1984 provides supplementary information that help us to reconstruct the water management history of Chongming. It is recorded that in the late Qing Dynasty, Chongming county magistrate stipulated that dredging must be performed once a year on all arterial rivers, and the responsibility and cost were shared by "Lipai", leaders of the then basic unit of a local community. Between 1921 to 1948, river dredging was mostly initiated by local political elites, and project costs were normally shared by beneficiaries or local inhabitants. Local government's financial contribution to projects was very limited. In the meantime, smaller projects such as the maintenance of

\footnotetext{
${ }^{2}$ Chongming County Chorography Draft (Chongming Xianzhi Gao), edited in 1960, reviewing previous historical records and documenting the history of Chongming from 1912 to 1949 in the Republican period.
} 
secondary rivers and ditches were treated by farmers as their own affair - they took the responsibility for what was perceived to be their waterway - without any guidance or supervision from government. While we would not wish to romanticize the experiences of rural dwellers or present a narrative that suggests a harmonious relationship between local people and their environment, there is nevertheless a sense of local knowledge of water management that is reproduced on almost daily basis. Practices surrounding water management help to create both a unique environment and sense of social identity. As we argue below, there is an increasing disconnect between people and place as non-local actors seek in various ways to manage the environment of the Island.

After the establishment of the PRC in 1949, there were efforts to promote more formal management of waterways, to make it more amenable to human needs (Shapiro 2001). Local government provided funds and mobilized cadres and the public to carry out a series of river dredging and remediation projects. These projects mainly covered the south-north arterial rivers. In terms of the secondary rivers and tertiary ditches, there are no explicit records of any maintenance works. However, there are reports of river banks collapsing and being repaired during the 1970s and 1980s. Guided by the County Revolutionary Committee and the Chongming County Water Conservancy Society, local communes (She Dui) ${ }^{3}$ experiencing river bank problems planted reeds and built buffer platforms to consolidate the riverbanks.

The maintenance efforts of communes in the early years of the PRC were seen by residents as somewhat similar to the collective river management that had previously prevailed. In our interviews with elderly indigenous people, they recalled the annual ditching and dredging led by a village "Production Team" (Sheng chan dui) ${ }^{4}$ :

"Guaranteeing the water is flowing is very important. Our field crops rely on it, and we need clean water for cooking and for washing. Every year or every two years, the Production Team will organize people to conduct ditching and dredging. Each household will send one or two people to join the team. Besides dredging the silted riverbed, we also reaped reeds, which then we used for firewood or handcrafts." ${ }^{5}$

Maintaining the watercourse was of great significance for local living and food production. More than that, though, water management was attached to strong personal emotions. Events and activities became ways of passing on knowledge and representing skillful management of the environment. As one of the indigenous residents shared with us:

"In the past, each household still owned a section of the riverbanks as part of their fields, which we used to call "Zhi Bian" 植边 (refers to the river slope or the river platform by the road). Every household treats their Zhi Bian carefully as it is part of our own lands, and as it also shows the characteristics of your family - if your vegetables or plantings are growing very well, the neighbors will praise you; and if not, then people might think you are not industrious or not skillful. Some families, like my grandparents, grew trees there. And I actually grew up with one of them as it was planted when I was born. However, they [Zhi Bian] no longer exist anymore."

\section{Water governance in eco-developments: state intervention}

\footnotetext{
${ }^{3}$ She Dui, also known as Sheng Chan Dui [Production Team], is an organizational form in China's socialist agricultural economy. It is the basic unit of labour organization in state farms, and in the rural areas, it is a cooperative economy of collective ownership by the working people.

${ }^{4}$ See footnote 4.

${ }^{5}$ Interview with an indigenous resident on 19 June 2017 in Mandarin, translated by Xie, L.
} 
The growing distance between local people and their management of the environment has become increasingly apparent and accelerated when the proposed Dongtan eco-development began to take shape. Over the years, under Shanghai Municipal Government's direct instructions, Chongming County/District Government has enforced a series of water measures. These were typically engineering led solutions to problems and included canalizing rivers to improve their flow to reduce flood risk and to secure riverbanks. From 2006 there were more systematic attempts at water regulation, and this coincided with the official announcement of the "Eco-Island" development plan (Shanghai Municipal Government, 2006). In November 2006, Chongming Water Authority and Chongming Finance Bureau (2006) jointly issued the Implementation Opinions on "Ten-Thousands Rivers Regulation Operation" (Wan He Zheng Zhi Xing Don), targeting 3,303-kilometers of river. There are nine requirements of this operation: 1 ) effectively remove mud from the river bottom; 2) clean the river gates; 3 ) remove illegal constructions by the riverbanks; 4 ) reconstruct blocked culverts; 5) better control sources of river pollution; 6) remove waste from the water and riverside; 7) maintain river bank slopes; 8) improve water quality; and 9) cover the riverbanks with greenery. Guided by these criteria, there was a rapid transformation of nearly 5,000 rivers on Chongming. In 2009, as a continuation of the "Operation", Chongming further implemented the "Village and House River Regulation" (Cun Gou Zhai He) and completed the modification of more than 4,000 village- and house- level rivers. Since 2011, another series of projects, including "Ecological River Regulation" (Sheng Tai He Dao Zheng Zhi), "Medium and Small Rivers Maintenance" (Zhong Xiao He Dao Yang Hu), and "Village-level Rivers Dredging" (Zhen Cun Ji He Dao Lun Shu), have been launched. Attempts to manage and regulate water continue with the Eco-Island construction. In the 13th Five-year Plan of Chongming World-class Eco-Island Development (Shanghai Municipal Government, 2016), a set of key performance indicators (KPIs) were stipulated, that provide criteria for quantitative measurement of the success or otherwise of the implementation of eco-island construction. Out of 17 indicators, there are four directly related to water management, namely Natural Wetland Retention Rate, Surface Water Environmental Functional Area Compliance Rate ${ }^{6}$ (to measure water quality), Urban Sewage Treatment Rate, and Rural Sewage Treatment Rate. All, except the Rural Sewage Treatment Rate which is an "anticipated" target are "obligatory" targets, so are 'must-be-completed' tasks for local government. Inevitably, these targets guide where resources are allocated and where attention is focused. Moreover, these are activities that government can manage directly to increase control over them. Almost by default, communities and their expertise are marginalized in resource management.

It is important to note that such significant state-led efforts at water management have achieved much. According to the Chongming District Master Plan \& Land Utilization Master Plan (2017-2035) (Shanghai Municipal Government, 2018), in 2016, Chongming District was able to safeguard $38.07 \%$ of its natural wetland, and there was an $85 \%$ urban sewage treatment rate. By way of contrast, the rural sewage treatment rate remains relatively low at $16 \%$. For local government there is considerable pride that $80 \%$ of the rivers in the Shanghai Municipality that meet the national Environmental Quality Standards for Surface Water are located in Chongming District (Shanghai Municipal Government, 2016).

Nevertheless, different voices were raised among indigenous people contesting the ecological measures enforced on the Island. Xu Gang, a renowned Chinese contemporary writer born in Chongming in 1945, has lamented the water quality change on Chongming:

\footnotetext{
${ }^{6}$ The Chinese national standard, GB3838-2002 - Environmental Quality Standards for Surface Water, mandates the water quality that applies to all surface water with functions such as rivers, lakes, canals, channels, reservoirs, etc. According to the Standard, surface water is classified into five categories according to their level of functions, ranging from National Nature Reserve, primary protected area of concentrated drinking water, rare aquatic habitat, to general industrial water use areas and agricultural water areas.
} 
"What makes Chongming people distraught is the change of the surface water quality on the Island. From the mid-to-late 1980s, due to the pollution of pesticides, fertilizers, and township enterprises, the clean ditches with drinkable water that were surrounded by reeds in my memory, no longer exist... In the 'Ten-Thousands Rivers Regulation Operation' ... The two sides of the rivers and ditches were flattened, and there are no reeds to be seen any more. We must understand that reed is the symbolic plant of Chongming Island for more than a thousand years. Its rich and developed root system can not only stabilize the ditch, but also play a role in purifying the water. So, why?" (Xu, 2009, $\mathrm{P} 67)^{7}$

Similar concerns were raised by many indigenous people during our field surveys. Other typical comments included:

"In the past, the river in front of our house was very clean. Every family went there to wash rice, vegetables, and sometimes clothes. At that time, the riverbanks were covered by reeds, and crabs and fishes were abundant in the river. So, in summer, children were playing in the river, swimming and trying to catch fishes or crabs. Now, the river is not as clean as it used to be, and no one uses it anymore." $^{\prime 8}$

"Before the eco-island construction ... reeds were all over the rivers. River water was very clean, and had a variety of creatures such as fish, shrimp, crabs and eels. That was the natural 'eco', but unfortunately it does not exist anymore." ${ }^{9}$

The widening gap on the one side between governmental initiatives to treat water pollution and to improve water quality and on the other side perceptions on the ground of adverse ecological effects point to the need for a closer examination of the changing water governance on Chongming. More particularly we need to analyze how the guiding logic and performance evaluation measures of the Eco-Island development have come to increasingly shape water management.

\section{The reshaping of water governance and management}

From a political ecology perspective, different groups' knowledge and diverse interests in "place" and "resources" result in divergent environmental measures (Bryant and Bailey, 1997, Neumann, 2005, Peet et al., 2011, Robbins, 2012). In understanding the changing governance of rivers and river banks on Chongming it is important to note the role of the main management bodies (represented by 'river cleaners' and 'river chiefs') and their adoption of non-ecological and engineering practices.

River cleaners were employed as part of the "Ten-thousand, Thousands and Hundreds Employment Project" (wanren qianbairen jiuye xiangmu). This was initiated in 2005 and aimed to help people experiencing employment difficulty, especially people in their forties and fifties (called "4050 groups") back into work (Chongming Social Construction Committee Office, 2013). River cleaning is one of the jobs providing by this project that does not require high levels of education or skills ${ }^{10}$. Alongside the launch of the "Ten-Thousands Rivers Regulation Operation" in 2006, Chongming Water Authority employed hundreds and thousands of cleaners managing rivers at all levels. Their main work tasks include watercourse cleaning and maintenance of green spaces. River cleaners were given clear performance

\footnotetext{
${ }^{7}$ Original texts are Chinese, translated by Xie, L.

${ }^{8}$ Interview with a local farmer on 29 August 2017 in Mandarin, translated by Xie, L.

${ }^{9}$ Interview with a local farmer on 13 February 2017 in Mandarin, translated by Xie, L.

${ }^{10}$ The other posts include forestry conservation, home-based cares, traffic management, community security, community assistance etc.
} 
assessment criteria that they had to work to ${ }^{11}$. An interview with a former "river cleaner" hired in 2007 has revealed details of his job:

"I am one of the first batch of river cleaners on Chongming. I remember each river cleaner was allocated an 840-meter long river section, and the main requirements include cleaning the water, clearing all kinds of cages and fast-growing aquatic plants to ensure smooth water flow, and to remove all reeds, wild rice shoots (jiao bai) and any other plants on the river banks within a year. There must be no plants by the river between the water surface up to 50 centimeters high. There will be monthly inspections and failure to deliver the tasks will lead to a salary deduction, which is often quite a lot. To accomplish the job, we used herbicides to clear the riverbanks. So, we are actually the 'reeds killer'"12.

Without proper guidance for their job, combined with a lack of ecological knowledge of the disastrous effects of herbicides, local river cleaners attempted to meet their job requirements (to gain their full salary) without knowing that their actions were simultaneously destroying the original river ecology. Moreover, ecological is being reinterpreted from traditional river management practices of working with nature to seeking clean, green managed spaces and rivers that are undisturbed by plants. An indication of the shift in practices is that reeds were planted by local communes under the guidance of county government in the 1970s and 1980s as one of the major measures to protect river banks from collapsing were now to be removed. Since rural sewage is largely discharged directly into the numerous rivers on the Island (and in 2016 , the rural sewage treatment rate was only $16 \%$, see above), without the water purification function of reeds, the water quality of Chongming's rivers rapidly deteriorated. A local resident in Hongqiao Village in Chongming, who is also an environmental activist, commented:

"From what I observed and experienced, Chongming suffered the worst ecological transformation in the past ten years [2007-17]. Those ecological projects enforced by the government are actually destroying our ecological nature day by day. The most severe problem is the river regulation. Projects enforced to harness rivers and riverbanks adopted traditional hardening techniques, cementing the original natural riverbank by impermeable concrete retaining walls, which cut off the exchange of material, energy and information between rivers and the banks, and thus disabled rivers' selfpurification abilities. Meanwhile, as the village sewage treatment has not been improved, the quality of processed wastewater that is directly emitted into rivers is very low, which profoundly threatens the river water environment. Consequently, rivers on the Island were persistently polluted, which gravely harms the aquatic organisms and further induces biodiversity loss ${ }^{13}$.

The engineering measures employed in river regulation projects that cemented riverbanks and elaborately trimmed the greenery by the river are in line with the guiding ecological modernization principles adopted in the eco-island plans. These ecological modernisation principles included emphasizing scientific and technical perspectives, especially of engineers and landscape designers come to the fore and marginalize local knowledge and expertise; an emphasis on resource efficiency (e.g. in land use, water flow), and urban aesthetics (e.g. in landscape design) (Pow, 2018); and the use of technology and techniques to manage the environment (e.g. straightening rivers). Whilst at more strategic policy and planning levels thinking may have been informed by ecological modernization their translation into revised working practices on the rivers showed limited knowledge of how to best manage the local

\footnotetext{
${ }^{11}$ Interview with officials from Chongming Water Authority on 18 June 2018 in Mandarin, translated by Xie, L.

12 Interview with a local "river cleaner" who was hired by the Chongming Water Authority from 2007 to 2009 to conduct river cleaning and maintenance on 12 September 2018 in Mandarin, translated by Xie, L.

${ }^{13}$ Interview with a local resident, also an environmental activist on February 13, 2017 in Mandarin, translated by Xie, L.
} 
environment. For example, a key set of practices are revealed through an examination of the River Chief System (Hezhang Zhi) initiated in early 2017 on Chongming. The Chongming River Chief System Office appointed the river chiefs for each river on the Island (normally held by a town cadre and the village head), and the river chiefs are responsible for the management of the river environment. Their working objectives, as clearly stated on an orange billboard put up on each river on Chongming, involve enforcing "no crops in the streambank and river platform, no illegal constructions, no piles, no garbage, no fallen trees, no floaters in the river surface, no obstructions in the river channel, no illegal emissions, no withered plants in and by the river". Typically, local officials are quick to respond to the superior governments' instructions, and in this case local cadres (river chiefs) on Chongming would seek the most efficient solutions that can generate rapid and visible effects (similar to river cleaners' adoption of herbicides). Cementing the river bank is one of the quick solutions to address all of the requirements stated on the billboard. Biodiversity and ecology are outside of the scope of performance assessment and thus out of local government officials' consideration during the development process. As a result, the previously diverse riverbanks, that had ecological value and meaning for local people are replaced by increasingly homogenous, clean and tidy riverbanks (Figure 2).

Figure 2. Typical riverbanks of Chongming that have been transformed during the river projects
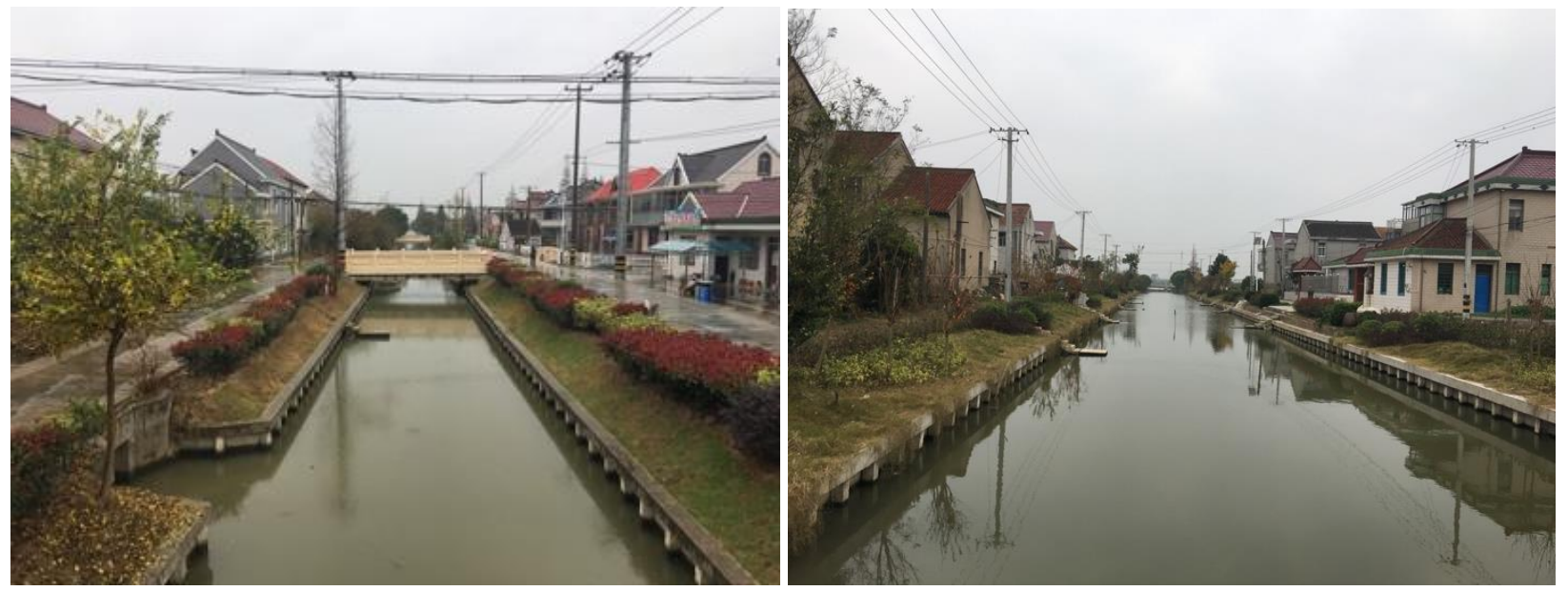

Source: Authors.

As river regulations are revised and diffused over rivers of all sizes on Chongming, the destructive and adverse effects of such government-led river governance quickly become apparent. Our field surveys also discovered many partially regulated rivers where one side of the riverbank has been hardened by a cement structure, and the other side's trees were recently cut down and only their roots remain that still hold together the slopes (Figure 4). We also found many "forgotten" rivers and ditches where it seems that villagers recognize their traditional maintenance role has been diminished and their efforts have not been replaced by local government workers. In these places water is stagnant and smelly (Figure 5). Ironically, local officials argue that one of the problems of current river management on Chongming is the limited participation of local inhabitants, which officials attribute to villager's weak awareness of environmental sanitation (Wang et al, 2014). However, we believe that when the government took over the river conservancy works and deprived people of their original responsibilities, rights and powers, local people naturally regarded river management as governmental work, which they have no right or duty (or even the courage) to interfere in. Political ecologists argue that the state's disproportionate and overwhelming influence in environmental interventions often lead to unintended and even pernicious 
socio-environmental results (Bryant and Bailey, 1997; Neumann, 2005; Peet et al., 2001; Robbins, 2012). The case of the transformation of Chongming river governance vividly illustrates the detrimental consequences that can arise when community-led river governance, that draws upon and reproduces local expertise, is replaced by a top-down perspective that relies on external professional knowledge and delivery practices and fails to sufficiently recognize the sensitivity of the local environment. The detachment of local communities from the management of their environment, and consequent adverse experiences for the Island's ecology, is repeated for land management as we shall see below.

Figure 4: Trees were cut down and their roots remain by the riverbank

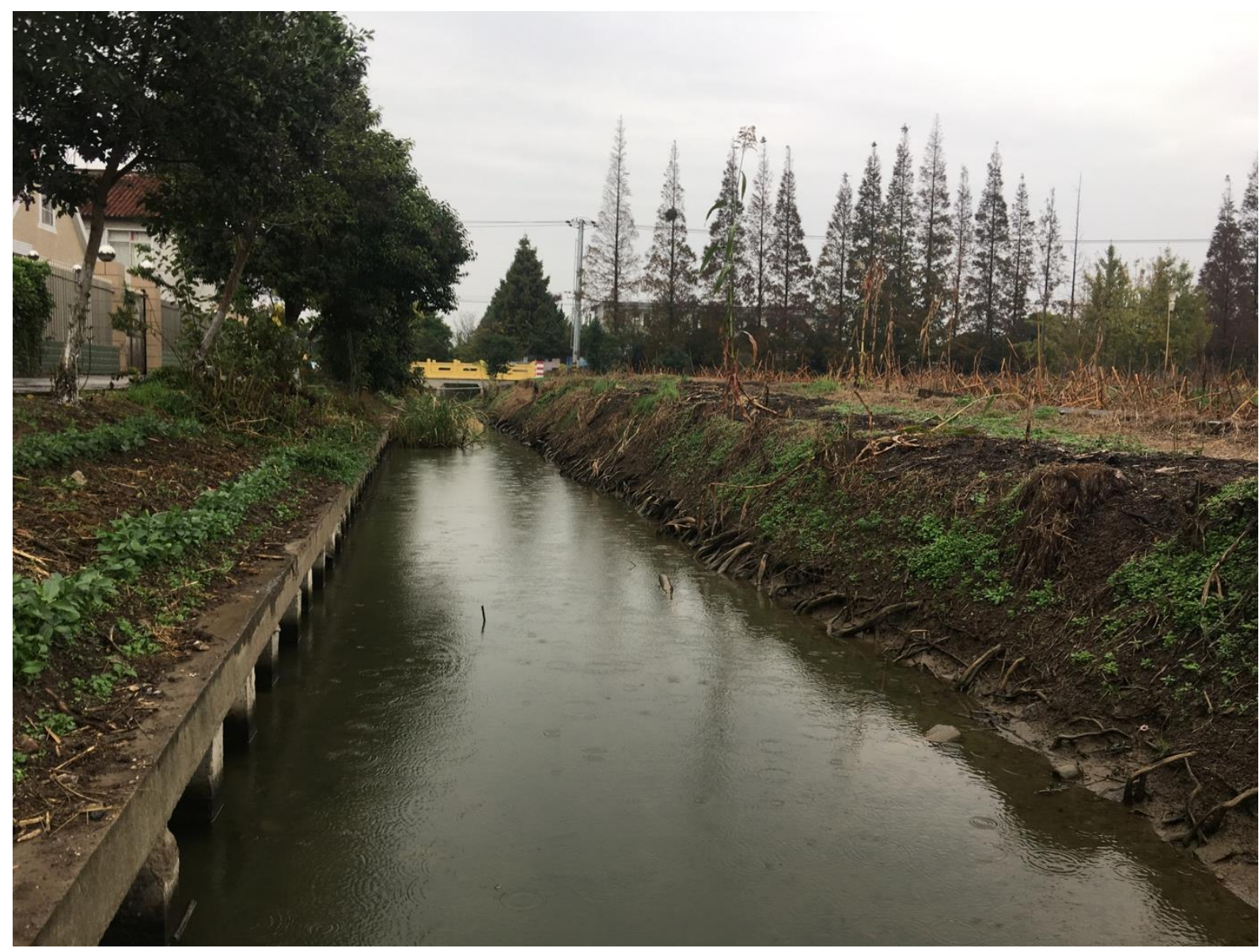

Source: Authors. 
Figure 5: "Forgotten" ditch on Chongming

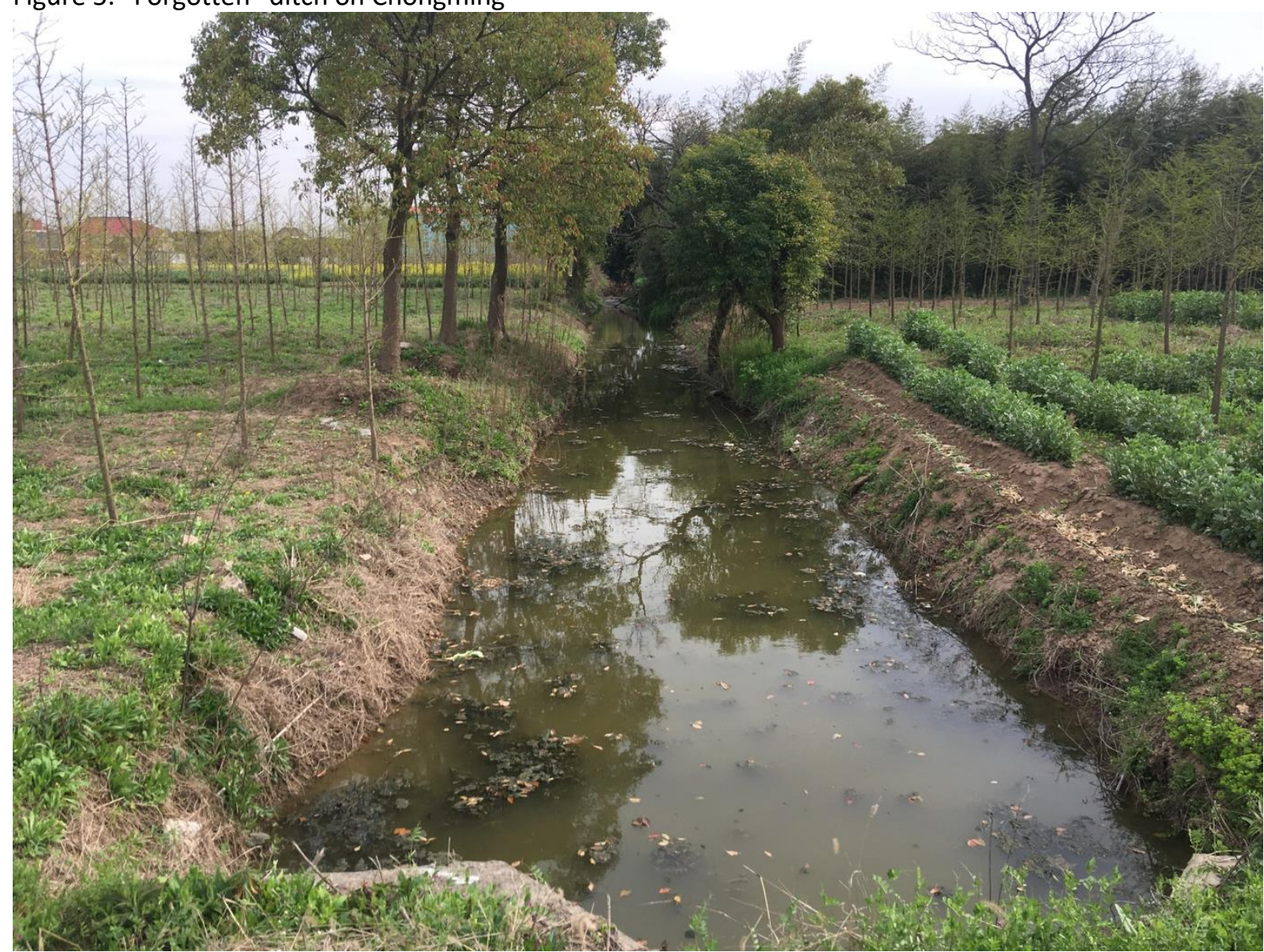

Source: Authors.

\section{Land governance: emerging "ecological enclosure"}

Whilst water plays a key part in shaping the environment of Chongming, land is hard-won and precious on the Island. Essentially the Island is a large estuary sandbank, open to erosion by currents and tides from the sea, and thus has an extremely unstable land base. Historical records show the frequent occurrences of natural disasters on Chongming ${ }^{14}$, resulting, for instance, in five relocations of the administrative base of Chongming. The dykes and dams, that are so integral to the water-based ecology of the Island, were built along the shore, and river water was channeled into the land. This complex wetland system provided abundant natural resources to support indigenous people's lives (such as reeds and fishing), and later people developed cotton and grain industries on the Island (Wei, 1983). Agriculture has long been the economic mainstay of the Island and most of its land is agricultural (Song, 2005). Farmers on Chongming used to call their lands "flower land" (hua di), and thus the heavy farm work has a very romantic name of "planting flower land" (zhong hua di) (Song, 2005). For them, the land they lived on and worked on is full of affection.

\footnotetext{
${ }^{14}$ Sources from Chongming County Chorography, which have a specific chapter for disasters records (titled Zaixiang (in Zhengde and Wanli Chorography), jinxiang (in Kangxi, Qianlong, and Yongzhong Chorography), or Zaiyi (in Minguo Chorography).
} 
In a similar way to water management (see above), with the establishment of the PRC in 1949, a much more interventionist approach to the environment emerged (Shapiro 2001). Large-scale and organized reclamations and cultivation have become a development feature. Since 1958, Chongming has been reassigned by the central government to be under the direct-control of Shanghai. This decision aimed to enlarge the suburban area of Shanghai to enable adequate food production for supporting the vast population in the city area. A massive reclamation programme was launched that targeted the seashore to extend the area of cultivated land as part of Shanghai government's determination to "transform the reed and grass marshes on Chongming into the city's food supply base" (Bian Chongming lutan, caotan wei chengshi fushipin gongying jidi) ${ }^{15}$. Until the advent of eco-development proposals, reclamation has been the main land development theme on Chongming.

Since the mid-1950s there have been regular and large-scale land reclamation activities (see Table 2 and Gong \& Cui, 2011). These have enabled the building of two new towns (Xincun Town and Luhua Town) and the creation of eight state-owned farms. Over more than six decades of reclamation, the area of Chongming has more than doubled, expanding from about 600 square kilometres in 1949 to around 1,267 square kilometres in 2018 (Figure 6). The most rapid period of urbanization occurred in the 1990s, when Chongming became a site for compensating the losses of arable land in Shanghai's suburbs due to the implementation of the Pudong Development Plan and other suburban development plans. While Chongming is continuously contributing land to the city of Shanghai, its once expansive wetlands have been severely damaged and are critically shrinking.

Table 2 Key land reclamation activities on Chongming Islands ${ }^{16}$

\begin{tabular}{|l|l|l|}
\hline Year & Size of reclamation (hectares) & No. of reclamations \\
\hline 1955 to 1984 & 40,837 & 55 \\
\hline 1985 to 1995 & 10,411 & 16 \\
\hline 1996 to 2010 & 12,961 & 14 \\
\hline
\end{tabular}

Source: Chongming County Annual Compilation Committee (1989); Shanghai Agricultural Reclamation Records Compilation Committee (2004); and Gong \& Cui (2010).

${ }^{15}$ http://zhengxie.shcm.gov.cn/cmzx wszl/2013-02-28/Detail 172969.htm.

${ }^{16}$ Chongming County/District consists of Chongming Island and two small surrounding islands, namely Changxing Island and Hengsha Island, which were transferred from the administration of Baoshan District of Shanghai to the jurisdiction of Chongming in 2005 (State Council, 2005). This paper focuses on Chongming Island but will touch on the other two islands when involving policies and plans that apply to all three islands. 
Figure 6: Reclamation on Chongming County/District since the 1950s.

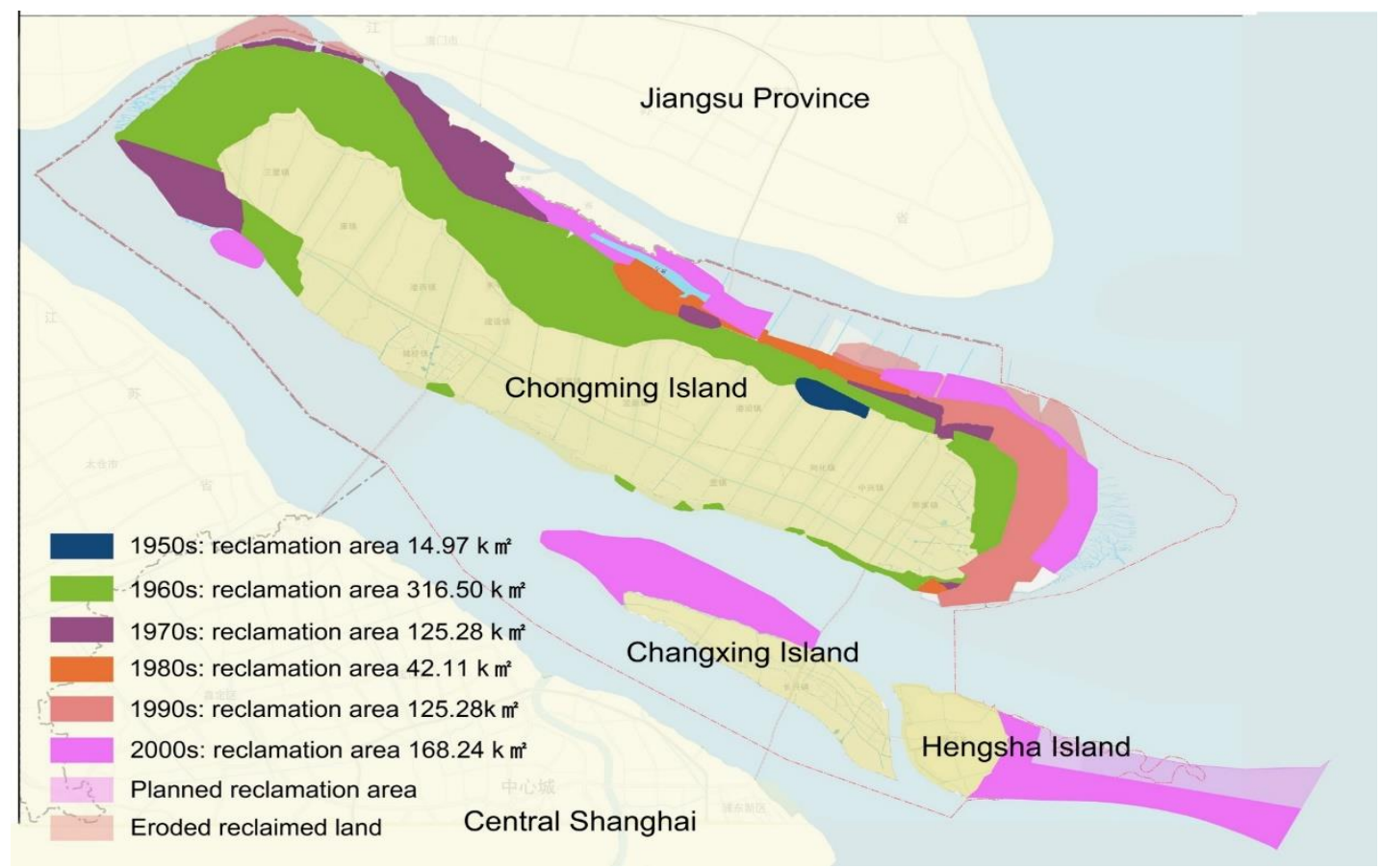

Source: compiled by authors based on Chongming County Chorography (Chongming County Annals Compilation Committee, 1989) and Shanghai Agricultural Reclamation Records (Shanghai Agricultural Reclamation Records Compilation Committee, 2004).

A more environmentally minded national and local state began to make its presence felt from the 1990s onwards. In 2006, the Eco-Island plan was officially announced by the Shanghai Municipal Government and the Chongming County Government. Nevertheless, after more than a decade, it seems that the grand plan of building Chongming into an Eco-Island has failed to curb the exploitation of local ecological resources and land resources. As we have seen in relation to water management above, the Chinese model of ecological modernization is infused with an anthropocentric approach to environmental protection and so both local people and their ecological practices are undermined. As the "strategic space for Shanghai's sustainable development in the 21st century" (Shanghai Municipal Government, 2001), the reclamation of coastal wetlands continues with numerous justifications, including the establishment of reservoirs, to compensate for the farmland occupation and exploitation that takes in Shanghai, and for reserving development land for Shanghai and Chongming.

Meanwhile, eco-island planning and development rather than curbing development seem to have also triggered a substantial reshuffle of the land ownership and use rights on Chongming. A series of opportunistic developments, not only real estate and tourism industries, but also agriculture and forestry, has been widely carried out on Chongming. These development projects are transforming the humanland relationship on the Island by dramatically changing local landscapes and local lives. For example, wetland reclamation continues, even within the designated natural reserve (see the case of Dongtan below). Perhaps the only significant difference to previous rounds of reclamation is that these lands are now under the management of the municipal government, and may be turned into agricultural landholdings to compensate for the farmland loss in the central city area, or developed into various 
industries, or even simply left idle. Here, we analyze two cases, namely the Dongtan area and the North Lake to explore in greater depth development pressures and their ecological and social consequences.

Dongtan, the eastern tip of Chongming Island where the Island meets the sea, has a vast wetland with abundant benthic and vegetation resources. It is a resting place for migratory birds and a wintering ground for waterfowl. 312 species of birds have been recorded in Dongtan. The importance of the area has been recognized and its status has been successively upgraded over time (see Table 3).

\section{Table 3 Designations of the Dongtan Nature Reserve}

\begin{tabular}{|l|l|}
\hline Year & Designation \\
\hline 1992 & $\begin{array}{l}\text { The China Biodiversity Conservation Action Plan formulated by the ten ministries and } \\
\text { commissions of the State Council listed Chongming Dongtan in the priority protection } \\
\text { sequence }\end{array}$ \\
\hline 1998 & $\begin{array}{l}\text { Chongming Dongtan Nature Reserve }\left(326 \mathrm{~km}^{2}\right) \text { established by Shanghai Municipal } \\
\text { Government }\end{array}$ \\
\hline 1999 & $\begin{array}{l}\text { Chongming Dongtan Nature Reserve joined the East Asian-Australasian Flyway network } \\
\text { sites }\end{array}$ \\
\hline 2001 & $\begin{array}{l}\text { Chongming Dongtan Nature Reserve was upgraded to a national nature reserve by the } \\
\text { State Council }\end{array}$ \\
\hline 2002 & $\begin{array}{l}\text { Chongming Dongtan Nature Reserve and the adjacent } 84 \text { square kilometres of } \\
\text { constructed wetland were listed as a Ramsar Site }\end{array}$ \\
\hline
\end{tabular}

However, records show that even during the period of increased protection - from the late 1990s to the early 2000s - several major reclamation projects were still carried out in the Dongtan area: in 1998, a total area of 67 square kilometers of land was reclaimed (Zhao, 2002); followed by another 22 square kilometers in 1999 (Xie et al, 2004); and in the winter of 2001, another 6 square kilometers. Due to the slow siltation of the tidal flats, reclaimed wetlands could not properly regenerate and function and the reclamation has caused severe damage to local biodiversity (Figure 7). According to a survey, the population of the migratory Little Swan, a national second-class protected bird, has dramatically decreased from 3,000-3,500 in the early 1990s to 51 by the winter of 2000 (Zhao, 2002). Ironically, as we probed into the intentions behind these reclamation activities within the Nature Reserve area, one of the justifications given was to treat the invasive plant - Spartina Alterniflora in the Reserve Area ${ }^{17}$, which was firstly introduced on Chongming in the mid-1990s to speed up the siltation process to facilitate reclamation and embankment consolidation (Chen, 2004).

\footnotetext{
${ }^{17}$ Interviews with a wetland ecology scholar based on Chongming and an official from Shanghai Chongming Water
} Authority on March and June 2018. 
Figure 7: Transformation of Dongtan area from 1997 to 2006 to 2016

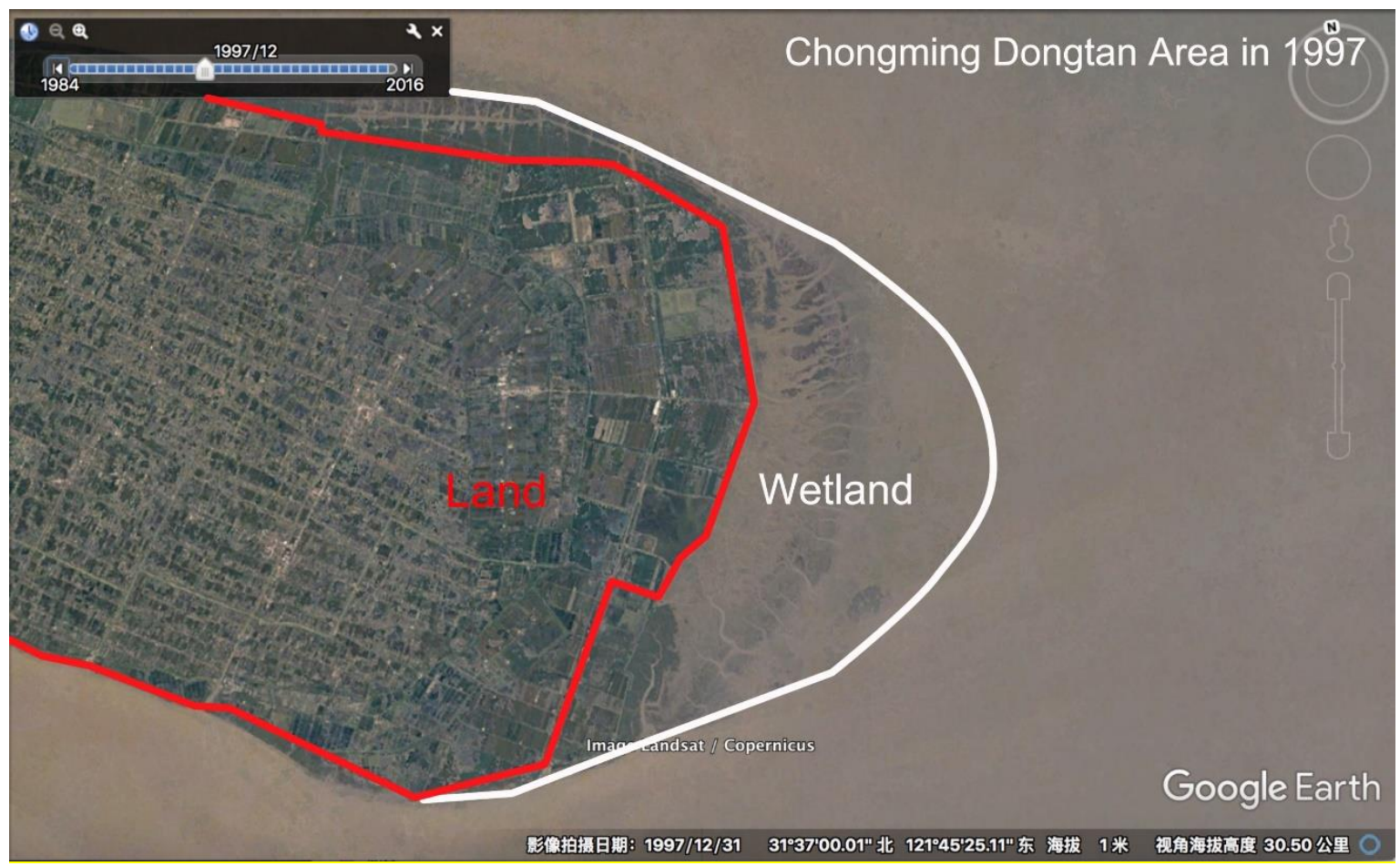

(2) Q Chongming Dongtan Area in 2000

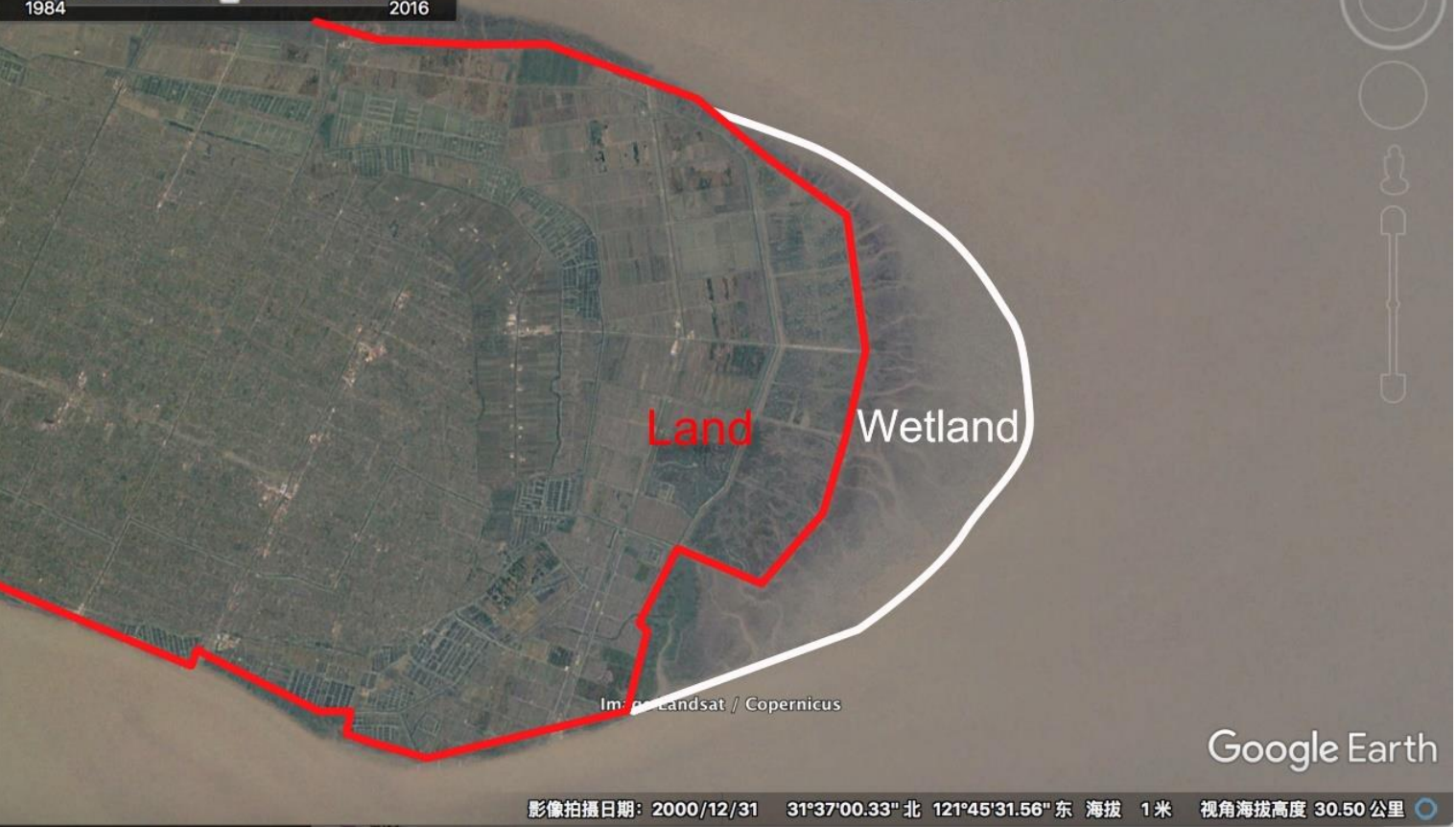




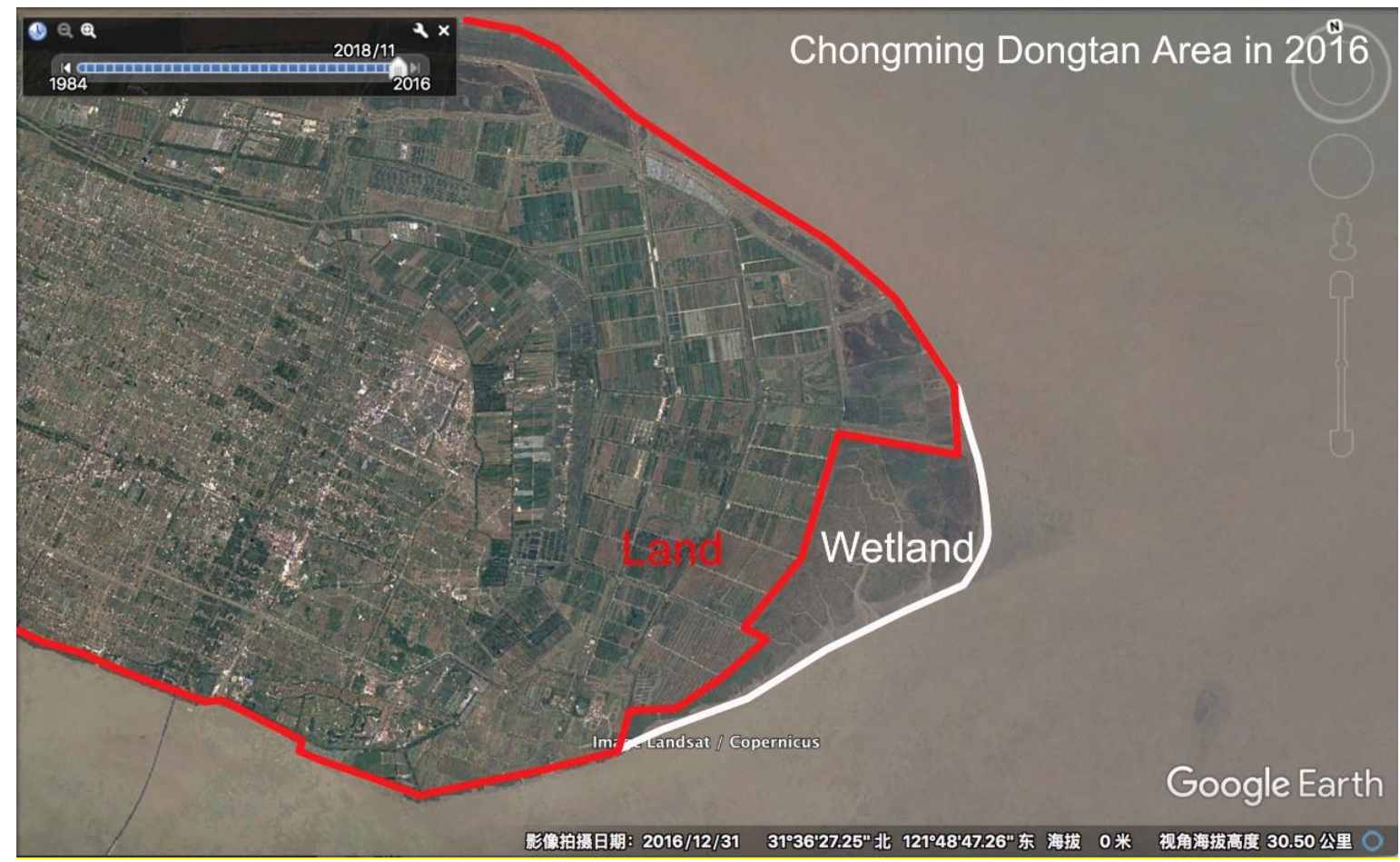

Source: compiled by authors based on Google Earth historical image

Vast stretches of farm land on Dongtan area as well as most of the newly reclaimed land (in total 85 square kilometers), were passed to the Shanghai Industrial Investment Corporation (SIIC), a municipality-owned property developer. In 2005, SIIC announced the high-profile Dongtan Eco-City plan, although since 2008 it has been indefinitely suspended. Among a complicated set of reasons for the suspension of the project are the state's increasingly strict regulation over the protection and conversion of cultivated land (Pow and Neo, 2013), as the 85 square kilometers of land owned by SIIC are all classified as agricultural land. The former resource-rich wetland, now a greenfield site, is largely idle, except for the 6.5 square kilometer Dongtan Wetland Park that has been built (where an artificial wetland has been created as a paid-access visitor attraction) and a recently completed 1.67 square kilometer elderly community (which remains largely vacant). The Dongtan case illustrates how land reclaimed from wetlands, at some ecological and social cost for the local community, can end up, at least in the short-term being idle or inefficiently used.

Another case illustrates how land management is subject to constant revision to meet policy demands from actors external to the Island. The power of reinterpretation lies firmly with actors in Shanghai who are able to appropriate meaning at the expense of more eco-centric or local values. In northern Chongming, the North Lake (Beihu) area became the subject of redevelopment in 2002 with the purpose of alleviating the tension between the supply and demand of construction land in the central city of Shanghai. To help realize the balance of cultivated land, the Shanghai municipal government implemented a reform of the tidal flat development management system and authorized the Shanghai Land Group (SLG), a state-owned enterprise, to examine the potential of developing tidal flats throughout the city area. The first project initiated by SLG, via a subordinate company - the Shanghai Tidal Land Requisition Company (STLRC) (tantu zaodi gongsi), was the reclamation of an artificial lake - Chongming North Lake - in 2003. The reclamation covered a total area of 30 square kilometres (including a water surface area of 17.6 square kilometres) and is owned by SLG, STLRC and the Shanghai Municipal Land Reserve Centre (which is affiliated to the land and resources management department of Shanghai) (Huang et al, 2005). However, 
15 years after it was reclaimed, there still appears no clear development or protection plan for the North Lake Area. It was only in 2017 that the deputy of the Municipal People's Congress, Wu Deping, pointed out that due to the lack of professional management, the North Lake had become a "wild lake" with deteriorating environment and potential security hazards (Wu, 2017). The use of the phrase "wild lake" is revealing as it shows that lakes, like other water areas, are to be managed in a manner that emphasises their aesthetic rather than their biodiverse value.

On our field trip to the North Lake in March 2018, a metal gate and a fence that is miles long blocked us from entry to the site (Figure 8). The notice attached to the gate says, "The Chongming North Lake area is a legally owned property of Shanghai Tidal Land Requisition Company. It is strictly forbidden for any individual or unit to enter without the permission of the company". The signing date is February 7, 2017. As the "legally owned property" of STLRC, North Lake is now an "enclave" that falls outside of Chongming's planning and administration. Since the North Lake reclamation project, STLRC has reclaimed a total of 182 square kilometres land on the three islands of Chongming County/District ( $W u, 2017)$. Being directly managed by the municipal government, Chongming government is left to provide help with routine supervision ${ }^{18}$.

Figure 8: The metal gate at the entrance of Chongming North Lake

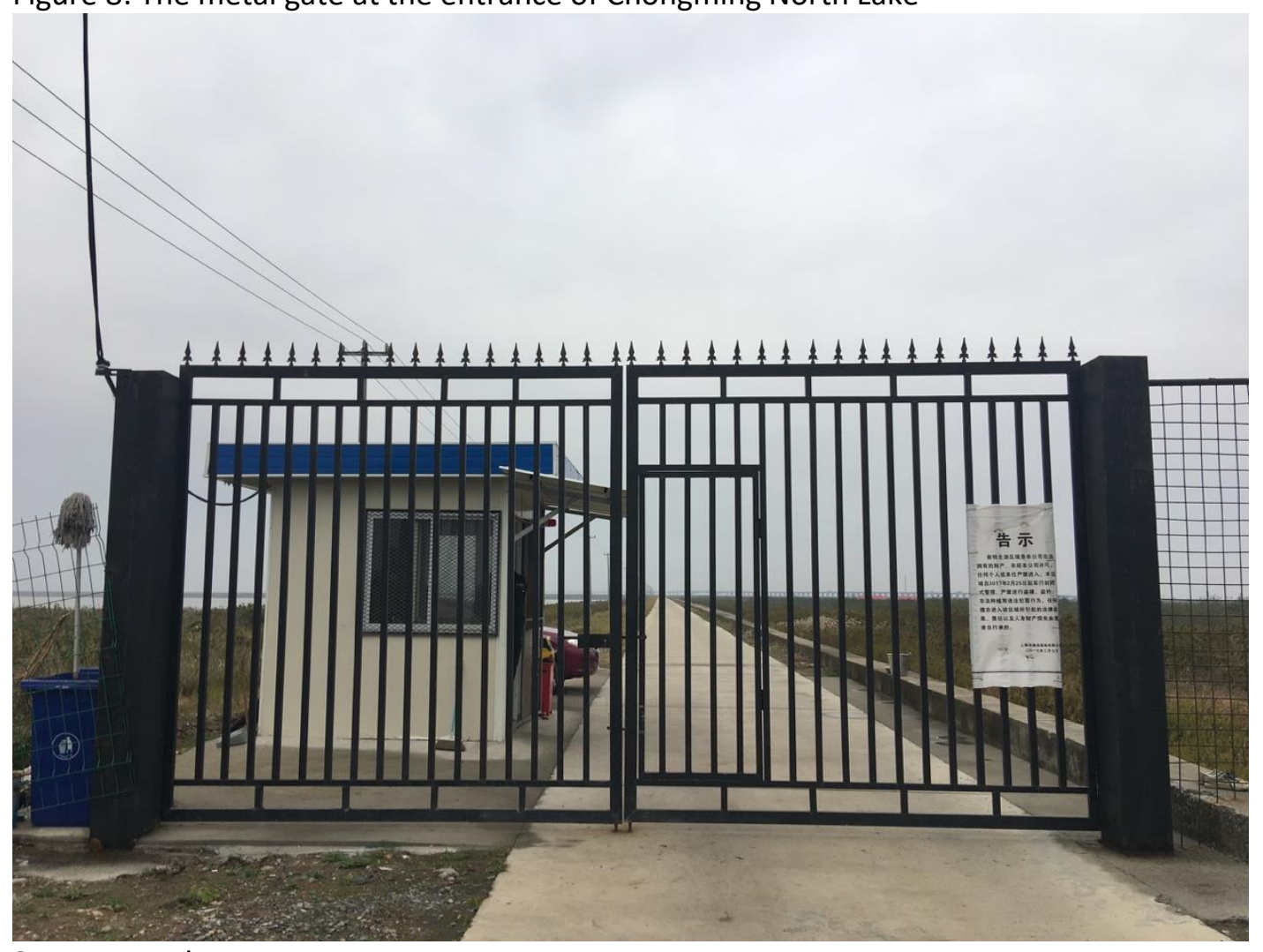

Sources: Authors.

\footnotetext{
${ }^{18}$ Interview with an official from Shanghai Chongming Water Authority on June 2018.
} 


\section{Conclusions}

In our Conclusions we reflect upon what our findings mean for our three research questions. We also offer some thoughts about the future direction of research on eco-developments in China. Our comments address both theory and practice.

How do state and local understandings of ecological management interact on Chongming Island? Our political ecology perspective has enabled us to bring together competing narratives for the development of Chongming Island. Local practices for water and land management helped nurture an environment that was cherished by its members. Ecological expertise was valued and sustained by day-to-day interactions with land and water as well as rituals and events, which well manifested the nature-culture binary that underscored political ecology (Yeh, 2009). Nevertheless, unequal power possessed by different stakeholders determined their effects on environmental changes (Bryant, 1998; Tan-Mullins et al., 2017b). As shown in Chongming, relations between local people and place are increasingly being broken as state actors gradually intervene in managing the environment and resources. Maoist efforts to control nature established the dominant role of the Shanghai Municipal Government over Chongming's land and nature. More recent state-led practices, even though these have been led by more environmentally informed policies and plans, have introduced notions of environmental management that are aesthetic and clean and draw on an external (Beijing and Shanghai) expertise that further marginalizes local knowledge. Shanghai's power and authority far outweighs that of the locality. So, the city's continuing drive for development results in farmland compensation from Chongming. This, in turn, leads to environmentally destructive reclamation and a loss of valued local environmental resources. While changes in access to land deny people the opportunity to visit (formerly public) tidal flats (wetlands).

How do communities respond to state-led eco-development? The dominance of ecological modernization thinking in plan making and delivery for the Island has been typified by engineering measures employed in constructing the environment. River banks, for example, have been replaced by concrete retaining walls. Chongming Eco-Island's planning ideology, on-the-ground practices, and its evolution over time reflect the specific contexts of China's socio-political climate and the unique features of Chinese eco-development practices - marked by a strong state, employment of ecological modernization methods and technocratic indicator-driven system with limited public engagement. Community concerns about the nature of development are voiced but have only very limited opportunities in which to be heard. This is for three reasons. Firstly, the strong executive power and capacity of the local state is demonstrated through the strict enforcement and swift execution of policies and plans. Secondly, guided by the principle of ecological modernization, measures employed to construct the eco-island are led by explicit indicator systems (Ma et al, 2017). Steered by "technological fixes" to meet quantifiable targets, local cadres adopted simplistic and engineering measures in regulating and constructing the environment, which has negligible appreciation of the local cultural and environmental context. Therefore, a neat and ordered urban landscape is being built that simultaneously harms the local ecology and communities. Thirdly, a significant problem identified in the Chongming Eco-Island case concerns an almost complete absence of local-level civic participation in policy-making and planning; the process is resolutely top-down (Yu, 2012). As those communities, who often are both the most dependent upon and the most knowledgeable about the local environment and resources, have difficulty achieving voice they have been largely left out of eco-island planning and development. 
How can we progress thinking on political ecology to better analyse multi-scalar state led environmental activities? In the paper we have shown how a political ecology perspective is enriched by a systematic engagement with a multitude of state activities. These include policy and planning where a Chinese version of ecological modernization (Zhang et al 2007) is influential in strategic thinking on the future of the Island as evidenced in Master Plans for instance; to the shifting perspectives of Shanghai Municipal Government on the ways in which it may utilise Chongming Island as a resource for the megacity (e.g. from a site of food production to place of landscape consumption). Policy making and delivery is topdown drawing on the elite knowledge of professionals from outside of the Island. Moreover, such knowledge draws on partial interpretations of the environment that emphasise aesthetic values over biodiversity as we showed with the canalisation of waterways. The challenges of top-down governance and increasingly marked discrepancies in interpretations of the environment as we move from a policy elite to those charged with managing the environment are starkly revealed by the actions of river cleaners and river chiefs. In this way, we can discern the tensions within an emerging Chinese environmental state as it grapples to make policy rhetoric meaningful in environmentally sensitive ways. These tensions become apparent on the ground because in contesting the current modernization thinking and development, local people contribute to a compelling counter narrative that could foster a more just and sustainable eco-island. By focusing on the interplay between people, place and environment, political ecology gives voices to local people's knowledge and desires, and thus enables the creation of more nature-focused, locally-relevant approaches to promote just planning for sustainable/ecological development.

Finally, we wish to offer some brief thoughts on future work on eco-development. First, our paper has successfully drawn out the competing interpretations of eco-development that can come from an ecological modernization focus on strategic policy and planning initiatives, and a political ecology informed perspective that explores individual and community perceptions of eco-development. While the former is more positive about managing the environment and of promoting change, the latter provides a more critical account of what change means in practice. Judgements on the successes or failures of ecodevelopments therefore need to be much more nuanced. The complex nature of eco-developments means that researchers need to be more sensitive to alternative and competing perspectives when designing projects and in interpreting results. Second, the novel nature of much eco-development means that time horizons are necessarily shortened. What we have shown here, though, is that the development story for a particular place does have deeper roots and we need to be sensitive to those. Our case studies need to understand the places that we are researching. Third, we must be aware of scale - the geographical boundaries - of our case studies. Much of the planning of the future of Chongming Island is taking place off the Island, in the offices of land use planners and engineers and in corporations such as Arup. We therefore need methods and conceptual frameworks that enable us to work comfortably at and between different scales. Finally, we need to ensure that the communities who are the objects of planning for eco-developments have their voices heard.

\section{Acknowledgement}

The authors would like to thank all anonymous referees for their insightful and constructive comments on previous versions of this paper. This work was supported by the National Natural Science Foundation of China (NSFC) [project number: 71461137005] and the Economic and Social Research Council (ESRC) 
[grant number ES/L015978/1]. We would like to thank all interview participants. Linjun Xie acknowledges partial support by the International Doctoral Innovation Centre at the University of Nottingham Ningbo China. 


\section{References}

Arup 2008. Fact Sheet For Dongtan Eco-City, London Arup Press Office

Barca, S. \& Bridge, G. 2015. Industrialization And Environmental Change. In: Perreault, T., Bridge, G. \& Mccarthy, J. (Eds.) The Routledge Handbook Of Political Ecology. London And New York: Routledge Taylor \& Francis.

Brown, C. J. \& Purcell, M. 2005. There's Nothing Inherent About Scale: Political Ecology, The Local Trap, And The Politics Of Development In The Brazilian Amazon. Geoforum, 36, 607-624.

Bryant, R. L. 1998. Power, Knowledge And Political Ecology In The Third World: A Review. Progress In Physical Geography, 22, 79-94.

Bryant, R. L. \& Bailey, S. 1997. Third World Political Ecology, London, Routledge.

Caprotti, F. 2014b. Eco-Urbanism And The Eco-City, Or, Denying The Right To The City? Antipode, 46, 1285-1303.

Caprotti, F., Springer, C. \& Harmer, N. 2015. 'Eco' For Whom? Envisioning Eco-Urbanism In The SinoSingapore Tianjin Eco-City, China. International Journal Of Urban And Regional Research, 39, 495-517.

Chan, K. W. 2015. Governance Of Sustainable Development: A Case Study Of The Bamboo Shoot Production Industry In Lin'an, China. Degree Of Doctor Of Philosophy Cardiff University

Chang, I. C. C. \& Sheppard, E. 2013. China's Eco-Cities As Variegated Urban Sustainability: Dongtan EcoCity And Chongming Eco-Island. Journal Of Urban Technology, 20, 57-75.

Chen, Z., 2004. Ecological impacts of the introduced Spartina alterniflora invasions in the coastal ecosystems of Chongming Dongtan, the Yangtze River estuary. Thesis submitted for Degree of Doctor Philosophy, Fudan University, School of Life Science.

Cheng, H. \& Hu, Y. 2010. Planning For Sustainability In China's Urban Development: Status And Challenges For Dongtan Eco-City Project. Jounal Of Environmental Monitoring 12, 119-26.

Chien, S.-S. 2013a. Chinese Eco-Cities: A Perspective Of Land-Speculation-Oriented Local Entrepreneurialism. China Information, 27, 173-196.

Chien, S.-S. 2013b. New Local State Power Through Administrative Restructuring - A Case Study Of PostMao China County-Level Urban Entrepreneurialism In Kunshan. Geoforum, 46, 103-112.

Chongming County Govnerment, 2016. "ECO+" as the development engine of Chongming [ “生态十” 成为崇明发展重要引擎]. [Online], Available at: http://www.shanghai.gov.cn/nw2/nw2314/nw2315/nw15343/u21aw1148417.html (accessed on August 26, 2017).

Chongming County Water Affairs Bureau (Marine Bureau), 2014. Bulletin of the Chongming County Water Affairs Bureau (Marine Bureau) and the relevant data on administrative business work[崇 明县水务局 (海洋局) 基本情况和行政业务工作有关数据情况公报]. Online: http://info.cjk3d.net/viewnews-869239 (accessed on 16 November 2018).

Chongming Water Authority and Chongming Finance Bureau, 2006. Implementation Opinions on “Wanhe Remediation Action” in Chongming County [崇明县 “万河整治行动” 实施意见]. Online: http://www.cmx.gov.cn/html/DefaultSite/shcm_xxgk_zfgb_200604_zfbgswj/2006-1121/Detail_5388.htm (accessed on 16 November 2018).

Chongming Social Construction Committee Office, 2013. Chongming County "Ten-thousand, Thousands and Hundreds People Employment Project": Exploring the Management Approach and Integration Effect[崇明县“万千百人就业项目”：探索管理之道收整合之效]. Online: http://www.shshjs.gov.cn/shjs/node8/u1a9264.html (accessed on 17 November 2018).

Clarke-Sather, A., 2017. State power and domestic water provision in semi-arid Northwest China: Towards an aleatory political ecology. Political Geography, 58, pp.93-103.

Cugurullo, F. 2015. Urban Eco-Modernisation And The Policy Context Of New Eco-City Projects: Where Masdar City Fails And Why. Urban Studies, 53, 2417-2433. 
De Jong, M., Joss, S., Schraven, D., Zhan, C. \& Weijnen, M. 2015. Sustainable-Smart-Resilient-Low Carbon-Eco-Knowledge Cities; Making Sense Of A Multitude Of Concepts Promoting Sustainable Urbanization. Journal Of Cleaner Production, 109, 25-38.

De Jong, M., Wang, D. \& Yu, C. 2013. Exploring The Relevance Of The Eco-City Concept In China: The Case Of Shenzhen Sino-Dutch Low Carbon City. Journal Of Urban Technology, 20, 95-113.

Den Hartog, H., Sengers, F., Xu, Y., Xie, L., Jiang, P., and de Jong, M., 2018, Low-carbon promises and realities: Lessons from three socio-technical experiments in Shanghai. Journal of Cleaner Production, 181: 692-702.

Fisher, D., R. \& Freudenburg, W., R. 2001. Ecological Modernization And Its Critics: Assessing The Past And Looking Toward The Future. Society \& Natural Resources, 14, 701-709.

Flynn, A., Yu, L., FEINDT, P. \& CHEN, C. 2016. Eco-cities, governance and sustainable lifestyles: The case of the Sino-Singapore Tianjin Eco-City. Habitat International, 53, 78-86.

Gong, R. \& Cui, C., 2011. Investigation and Analysis of the Current Situation of Reclamation on Chongming Islands[崇明三岛滩涂围叚现状调查分析]. Shanghai Water, 27(4): pp. 20-21, \& p. 29.

Grydehøj, J. A. \& Kelman, I. 2016. Island Smart Eco-Cities: Innovation, Secessionary Enclaves, And The Selling Of Sustainability. Urban Island Studies, 2, Pp. 1-24.

Head, P. R. \& Lawrence, J. G. Urban Development To Combat Climate Change: Dongtan Eco-City And Risk Management Strategies. In: Wood, A., Ed. Ctbuh 8th World Congress, 2008 Dubai, Uae. Council On Tall Buildings And Urban Habitat, 244-251.

Hodson, M. \& Marvin, S. 2010. Urbanism In The Anthropocene: Ecological Urbanism Or Premium Ecological Enclaves? City, 14, 298-313.

Huang, Z., Ni, G., Huang, Q., Fan, Z., Gao, F., and Gong, L., 2005. Investigation report on water quality and aquatic living resources in Chongming North Lake[崇明北湖水质及水生生物资源调查报 告]. Fisheries Science \& Technology Information. 32(4): 167-168.

Hult, A. 2013. Swedish Production Of Sustainable Urban Imaginaries In China. Journal Of Urban Technology, 20, 77-94.

Hult, A. 2015. The Circulation Of Swedish Urban Sustainability Practices: To China And Back. Environment And Planning A, 47, 537-553.

Hult, A. 2017. Unpacking Swedish Sustainability: The Promotion And Circulation Of Sustainable Urbanism. Ph.D., Kth Royal Institute Of Technology.

Hung, L. \& Sheu, J. 2010. The Political Ecology Of A Rual-Urban Interface: Resources, Places And Local Attitudes Toward Guandu Nature Park [交界帶的政治生態學一居民對於關渡自然公園作為

「資源」與「地方」的看法]. Journal Of Geographical Science [地理學報], 60, 1 - 22.

Joss, S. 2011. Eco-Cities: The Mainstreaming Of Urban Sustainability - Key Characteristics And Driving Factors. International Journal Of Sustainable Development And Planning, 6, 268 - 285.

Joss, S., Cowley, R. \& Tomozeiu, D. 2013. Towards The 'Ubiquitous Eco-City': An Analysis Of The Internationalisation Of Eco-City Policy And Practice. Urban Research \& Practice, 6, 54-74.

Joss, S. \& Molella, A. P. 2013. The Eco-City As Urban Technology: Perspectives On Caofeidian International Eco-City (China). Journal Of Urban Technology, 20, 115-137.

Joss, S., Tomozeiu, D. \& Cowley, R. 2011. Eco-Cities - A Global Survey 2011. University Of Westminster.

Keil, R. 2003. Urban Political Ecology 1. Urban Geography, 24, 723 - 738.

Keil, R. \& Desfor, G. 2003. Ecological Modernisation In Los Angeles And Toronto. Local Environment, 8, 27-44.

Krueger, R. \& Gibbs, D. 2007. The Sustainable Development Paradox: Urban Political Economy In The United States And Europe, New York, Guilford Press. 
Leff, E. 2015. The Power-Full Distribution Of Knowledge In Political Ecology: A View From The South. In: Perreault, T., Bridge, G. \& Mccarthy, J. (Eds.) The Routledge Handbook Of Political Ecology. London And New York Routledge Taylor \& Francis.

Ma, X., De Jong, M. \& Den Hartog, H. 2017. Assessing the implementation of the Chongming Eco Island policy: What a broad planning evaluation framework tells more than technocratic indicator systems. Journal of Cleaner Production, 172: 872-886.

MEP (Ministry of Environmental Protectioon of the People's Republic of China), 2002. Decision on naming the second batch of the National Ecological Demonstration Zone and commending outstanding individuals and institutions [关于命名第二批国家级生态示范区及表彰先进的决 定]. Available at: http://www.mep.gov.cn/gkml/zj/wj/200910/t20091022 172084.htm (accessed on August 8, 2017).

Mol, A. P. 2003. Globalization And Enviornmental Reform Cambridge Ma: Mit Press.

Mol, A. P. J. \& Spaargaren, G. 2000. Ecological Modernisation Theory In Debate: A Review. Environmental Politics, 9, 17-49.

Mol, A. P., Spaargaren, G. \& Sonnenfeld, D. 2009. Ecological Modernisation: Three Decades Of Policy, Practice And Theoretical Reflection. In: Mol, A. P. J., Sonnenfeld, D. A. \& Spaargaren, G. (Eds.) The Ecological Modernisation Reader. Environmental Reform In Theory And Practice. London/New York: Routledge

Muldavin, J. 2013. From Rural Transformation To Global Integration: Comparative Analyses Of The Environmental Dimensions Of China's Rise. Eurasian Geography And Economics, 54, 259-279.

Neo, H. \& Pow, C. P. 2015. Eco-Cities And The Promise Of Socio-Environmental Justice. In: Bryant, R. L. (Ed.) The International Handbook Of Political Ecology. Edward Elgar Pub.

Neumann, R. P. 2005. Making Political Ecology London, Hodder Arnold.

Peet, R., Robbins, P. \& Watts, M. 2011. Global Political Ecology Abingdon, Uk, Routledge

Pow, C.P., 2018. Building a harmonious society through greening: ecological civilization and aesthetic governmentality in China. Annals of the American Association of Geographers, 108(3): 864-883.

Pow, C. P. \& Neo, H. 2013. Seeing Red Over Green: Contesting Urban Sustainabilities In China. Urban Studies, 50, 2256-2274.

Prytherch, D. L. 2002. Selling The Eco-Entrepreneurial City: Natural Wonders And Urban Stratagems In Tucson, Arizona. Urban Geography, 23, 771-793.

Rapoport, E. \& Hult, A. 2017. The Travelling Business Of Sustainable Urbanism: International Consultants As Norm-Setters. Environment And Planning A, 49, 1779-1796.

Robbins, P. 2011. Political Ecology : A Critical Introduction., Hoboken, New Jersey, Wiley-Blackwell.

Robbins, P. \& Sharp, J. 2003. The Lawn-Chemical Economy And Its Discontents. Antipode, 35, 955-979.

Shapiro, J., 2001. Mao's war against nature: Politics and the environment in revolutionary China. Cambridge University Press.

Shanghai Municipal Government, 2001. Shanghai Urban Master Plan (1999-2020). Shanghai: Government Document

Shanghai Municipal Government, 2006. Overall Plan for Chongming Three Islands. Available at: http://www.shsz.org.cn/book/shownews.asp?num=szzz-2006929154014 (accessed August 7, 2017).

Shanghai Municipal Government, 2016. Notice of the Municipal Government on Printing and Distributing the 13th Five - Year Plan of Chongming World - class Ecological Island Development [市政府关于 印发《崇明世界级生态岛发展“十三五”规划》的通知. Available at: http://www.shanghai.gov.cn/nw2/nw2314/nw2319/nw12344/u26aw50776.html (accessed on August 19, 2017).

Shanghai Municipal Government, 2018. Chongming District Master Plan \& Land Utilization Master Plan (2017-2035) [崇明区总体规划暨土地利用总体规划（2017-2035）]. Available at: 
http://www.cmx.gov.cn/UpLoadPath/2018/5/30/b1d3c678-6619-4f41-b6a0-7e72daa4c412.pdf (accessed on 24 June, 2018).

Shao, Z. 2015. New Eco-City, Low-Carbon New City, Low-Carbon Eco-City, Sun City. In: Shao, Z. (Ed.) The New Urban Area Development: A Case Study In China. Springer Berlin Heidelberg.

Song, C., 2005. Ecological Chongming [生态崇明], Shanghai: Shanghai Far East Publishers.

Swyngedouw, E. 1997. Power, Nature, And The City. The Conquest Of Water And The Political Ecology Of Urbanization In Guayaquil, Ecuador: 1880-1990. Environment And Planning A, 29, 311-332.

Swyngedouw, E. 2004. Scaled Geographies: Nature, Place, And The Politics Of Scale. In: Mcmaster, R. \& Sheppard, E. (Eds.) Scale And Geographic Inquiry: Nature, Society And Method. Blackwell Publishers. Oxford And Cambridge, Mass: Blackwell Publishers.

Sze, J. 2015. Fantasy Islands: Chinese Dreams And Ecological Fears In An Age Of Climate Crisis. University Of California Press.

Tan-Mullins, M., Urban, F. \& Mang, G. 2017. Evaluating The Behaviour Of Chinese Stakeholders Engaged In Large Hydropower Projects In Asia And Africa. The China Quarterly, 230, 464-488.

UNEP 2014. Chongming Eco-Island International Evaluatuion Report. United Nations Environment Programme.

Wang, D., Lai, H., and Lu, J., 2014. 崇明县中小河道管理存在的问题及对策 [Problems and Solutions of Small Rivers Management in Chongming]. Shanghai Water. 30 (3): 84-86.

Wang, R.Y., Liu, T. and Dang, H., 2018. Bridging critical institutionalism and fragmented authoritarianism in China: An analysis of centralized water policies and their local implementation in semi-arid irrigation districts. Regulation \& Governance. 12(3):451-465.

Wei, S., 1983. The Historical Process of the Formation, Evolution and Development of Chongming Island [崇明岛的形成、演变及其开发的历史过程]. Academy Monthly, 4: 71-77 \& 54.

Wu, D., 2017. Suggestions on the Localization Management of Agricultural Land in Chongming Three Islands Circle [关于崇明三岛圈围的农业用地属地化管理的建议]. Proposal for Shanghai Municipal People's Congress, Online: http://www.spcsc.sh.cn/n1939/n3144/n4115/index.html (accessed 18 November 2018).

Xie, L. 2015. Political Participation And Environmental Movements In China. In: Bryant, R. L. (Ed.) International Handbook Of Political Ecology. Cheltenham, Uk · Northampton, Ma, Usa: Edward Elgar.

Xie, L., Flynn, A., Tan-Mullins, M., and Cheshmehzangi, A., 2019. The making and remaking of ecological space in China: the political ecology of Chongming Eco-Islands. Political Geography.69: 89-102.

Xu, G., 2009. Chongming Island Biography [崇明岛传]. China Writers Publishing House. Beijing.

Zhao, G., 2002., What does Chongming wetlands mean to Shanghai [崇明湿地对上海意味着什么]. China Environment News. 3rd July 2002.

Zhang, L., Mol, A. P., \& Sonnenfeld, D. A. (2007). The interpretation of ecological modernisation in China. Environmental politics, 16(4), 659-668.

Yeh, E. T. 2009. Greening Western China: A Critical View. Geoforum, 40, 884-894.

Yeh, E. T. 2015. Political Ecology In And Of China. In: Bryant, R. L. (Ed.) The International Handbook Of Political Ecology. Cheltenham, Uk · Northampton, Ma, Usa: Edward Elgar Publishing

Yu, L. 2012. Critical Analysis Of Problems In Chinese Eco-City Development [对中国生态城现状问题的 批判性分析]. New Architecture[ 新建筑], 4: 25-6.

Yu, L. 2014. Low Carbon Eco-City: New Approach For Chinese Urbanisation. Habitat International, 44, 102-110. 